\title{
Treatment of Coronavirus Disease 2019 Patients with Convalescent Plasma Reveals a Signal of Significantly Decreased Mortality
} Check for updates

Eric Salazar, ${ }^{\dagger \dagger}$ Paul A. Christensen, ${ }^{*}$ Edward A. Graviss, ${ }^{* \star}$ Duc T. Nguyen, ${ }^{\ddagger}$ Brian Castillo, ${ }^{*}$ Jian Chen, ${ }^{*}$ Bevin V. Lopez, Todd N. Eagar, ${ }^{\dagger}$ Xin Yi, ${ }^{* \dagger}$ Picheng Zhao, ${ }^{*}$ John Rogers, ${ }^{*}$ Ahmed Shehabeldin, ${ }^{*}$ David Joseph, ${ }^{*}$ Christopher Leveque, ${ }^{*}$ Randall J. Olsen, ${ }^{* \dagger \ddagger}$ David W. Bernard, ${ }^{* \dagger}$ Jimmy Gollihar, ${ }^{\Uparrow}$ and James M. Musser ${ }^{\star \dagger \ddagger}$

From the Department of Pathology and Genomic Medicine,* Houston Methodist Hospital, Houston, Texas; the Department of Pathology and Laboratory Medicine, ${ }^{\dagger}$ Weill Cornell Medical College, New York, New York; the Center for Molecular and Translational Human Infectious Diseases ${ }^{\ddagger}$ and the Academic Office of Clinical Trials, ${ }^{\S}$ Houston Methodist Research Institute, Houston, Texas; and the Combat Capabilities Development Command Army Research Laboratory-South, "University of Texas at Austin, Austin, Texas

Accepted for publication August 3, 2020.

Address correspondence to James M. Musser, M.D., Ph.D., Houston Methodist Hospital, 6565 Fannin St., Ste. B490, Houston, TX 77030. E-mail: jmmusser@houstonmethodist. org.

\begin{abstract}
Coronavirus disease 2019 (COVID-19), caused by severe acute respiratory syndrome coronavirus 2, has spread globally, and proven treatments are limited. Transfusion of convalescent plasma collected from donors who have recovered from COVID-19 is among many approaches being studied as potentially efficacious therapy. We are conducting a prospective, propensity score-matched study assessing the efficacy of COVID-19 convalescent plasma transfusion versus standard of care as treatment for severe and/or critical COVID-19. We present herein the results of an interim analysis of 316 patients enrolled at Houston Methodist hospitals from March 28 to July 6, 2020. Of the 316 transfused patients, 136 met a 28-day outcome and were matched to 251 non-transfused control COVID-19 patients. Matching criteria included age, sex, body mass index, comorbidities, and baseline ventilation requirement 48 hours from admission, and in a second matching analysis, ventilation status at day 0 . Variability in the timing of transfusion relative to admission and titer of antibodies of plasma transfused allowed for analysis in specific matched cohorts. The analysis showed a significant reduction $(P=0.047)$ in mortality within 28 days, specifically in patients transfused within 72 hours of admission with plasma with an anti-spike protein receptor binding domain titer of $\geq 1: 1350$. These data suggest that treatment of COVID-19 with high anti-receptor binding domain IgG titer convalescent plasma is efficacious in early-disease patients. (Am J Pathol 2020, 190: 2290-2303; https://doi.org/10.1016/j.ajpath.2020.08.001)
\end{abstract}

Coronavirus disease 2019 (COVID-19), caused by severe acute respiratory syndrome coronavirus 2 (SARS-CoV-2), continues to spread globally and cause massive societal disruption and death. As of August 3, 2020, COVID-19 has been responsible for $>18$ million cases and approximately 690,000 deaths worldwide (Johns Hopkins University \& Medicine, https://coronavirus.jhu.edu/map.html, last accessed August 3, 2020). The United States is in the midst of a substantial surge of new cases, and despite months of effort, few treatment options with proven efficacy for COVID-19 are available. Currently, hundreds of registered clinical trials are underway, most of which are assessing antiretroviral agents, anti-inflammatory or immunosuppressant therapies, and passive antibody treatments. ${ }^{1-3}$ The antiretroviral remdesivir, an RNA polymerase inhibitor with activity against SARS-associated coronavirus and Middle East respiratory syndrome coronavirus, ${ }^{4}$ has shown promise in a recent randomized controlled trial, ${ }^{5}$ reducing recovery time in certain COVID-19 patients. In addition, dexamethasone was recently shown to reduce

Supported by the Fondren Foundation (J.M.M.), the Houston Methodist Hospital (J.M.M.), and the Houston Methodist Research Institute (J.M.M.).

Disclosures: E.S. is the local principal investigator for a clinical trial sponsored by Regeneron assessing an investigational therapy for coronavirus disease 2019. 
mortality in patients receiving oxygen, including mechanically ventilated patients. ${ }^{6}$ Many vaccines are in various stages of development, and one is being studied in a phase 3 trial, ${ }^{7}$ but it will be at least many months before an efficacious vaccine is available., ${ }^{8,9}$ Thus, although many prophylactic and therapeutic strategies are under investigation, the primary management of COVID-19 remains supportive care.

Convalescent plasma therapy has been used to treat patients during previous coronavirus outbreaks, ${ }^{10-13}$ the 2009 H1N1 epidemic, ${ }^{14}$ and the Ebola outbreak. ${ }^{15}$ Thus, early in the current pandemic, convalescent plasma therapy was proposed as a potential therapeutic and prophylactic option. ${ }^{16}$ The Food and Drug Administration rapidly made pathways available for the administration or study of COVID-19 convalescent plasma, and convalescent plasma remains the only widely available passive antibody therapy. Under the federally supported expanded access program coordinated by Mayo Clinic, as of July 11, 2020, >34,000 patients have been transfused with convalescent plasma (Mayo Clinic, https://www. uscovidplasma.org, last accessed July 11, 2020), with minimal adverse events. ${ }^{17}$ Similar safety findings have been shown in other studies. ${ }^{18-23}$

We recently published our early experience with convalescent plasma treatment in 25 patients with severe COVID$19 .{ }^{19}$ By day 14 post-transfusion, 19 patients $(76 \%)$ had improved or been discharged. ${ }^{19}$ However, conclusions regarding efficacy were hindered by lack of a control group, administration of concomitant antiretroviral and immunosuppressant therapies, non-standardization of anti-SARS-CoV-2 antibodies in donated plasma, and variation in disease severity at baseline (day of transfusion) in the plasma recipients.

To further investigate these initial observations, we are conducting a prospective, propensity score-matched study assessing the efficacy of COVID-19 convalescent plasma transfusion versus standard of care as treatment for severe and/or critical COVID-19. The study is ongoing, with 316 patients transfused to date. Herein, the results of an interim analysis are reported. The data suggest that transfusion of high anti-spike protein receptor binding domain (RBD) IgG titer convalescent plasma early in hospital admission reduces mortality by 28 days post-transfusion.

\section{Materials and Methods}

This prospective, ongoing study analyzed data from the eight Houston Methodist hospitals from March 28, 2020, through July 6, 2020, with the approval of the Houston Methodist Research Institute ethics review board and with informed patient or legally authorized representative consent. Patients were treated under an investigational new drug application approved by the US Food and Drug Administration (https://www.fda.gov/emergency-prepar edness-and-response/mom-legal-regulatory-and-policyframework/emergency-use-authorization, last accessed
July 11, 2020). Approval to treat the first patient was granted on April 3, 2020. Four patients treated under an emergency investigational new drug application were approved between March 28, 2020, and April 3, 2020, and were also included in the analysis.

\section{Patients}

COVID-19 patients admitted to any of the eight Houston Methodist hospitals were considered for enrollment in this trial. SARS-CoV-2 infection was diagnosed by real-time RT-PCR test, as described previously. ${ }^{19,24,25}$ Patients were eligible for this study if they had severe and/or life-threatening COVID-19 (US Food and Drug Administration, https://www.fda.gov/regulatory-information/searchfda-guidance-documents/investigational-covid-19-convalescentplasma, last accessed July 11, 2020). Severe disease was defined as one or more of the following: shortness of breath (dyspnea), respiratory rate $\geq 30 /$ minute, blood oxygen saturation $\leq 93 \%$ (on room air), partial pressure of arterial oxygen/fraction of inspired oxygen ratio $<300$, and/or pulmonary infiltrates $>50 \%$ within 24 to 48 hours (of screening assessment). Life-threatening disease was defined as one or more of the following: respiratory failure, septic shock, and/or multiple organ dysfunction or failure. Patient recruitment early in the study involved investigators reaching out to treatment teams and patients. As the pandemic progressed in the Houston metropolitan region and awareness regarding convalescent plasma as a treatment option increased, recruitment into the study transitioned to the study investigators screening requests for enrollment of patients from treatment teams across the hospital system. Fewer patients with advanced disease (intubated/on extracorporeal membrane oxygenation) were enrolled later in the study. Patients were excluded if: there was a history of prior severe reactions to transfusion of blood products with imputability of probable or definite, as defined by the CDC National Healthcare Safety Network Hemovigilance Module ${ }^{26}$; they had underlying uncompensated and untreated end-stage disease; and/or patients had fluid overload or other conditions that would contraindicate administration of plasma.

Patients were transfused with one or two units of COVID-19 convalescent plasma. Criteria for a second transfusion included, but were not limited to: worsening imaging findings (X-ray/computed tomography) thought to be due to COVID-19; increasing oxygenation requirement thought to be due to COVID-19; worsening partial pressure of oxygen/fraction of inspired oxygen ratio thought to be due to COVID-19; worsening hemodynamic status thought be due to COVID-19; new end-organ failure thought to be due to COVID-19; or body mass index $>30$ $\mathrm{kg} / \mathrm{m}^{2}$. As plasma inventory was limited early in the study, a second unit was not always available. Transfusion of a second unit was also influenced by patient enrollment in other trials that prohibited additional doses of convalescent plasma. 
Table 1 Baseline Characteristics in Cohorts of Secondary Matched Patients

\begin{tabular}{|c|c|c|c|c|c|c|c|c|c|c|c|c|}
\hline \multirow{2}{*}{ Characteristic } & \multicolumn{4}{|c|}{$\begin{array}{l}\text { Secondary matched, transfused } \\
\text { within } 72 \text { hours of admission }\end{array}$} & \multicolumn{4}{|c|}{$\begin{array}{l}\text { Secondary matched, transfused } \\
>72 \text { hours after admission }\end{array}$} & \multicolumn{4}{|c|}{$\begin{array}{l}\text { Secondary matched, transfused } \\
\text { within } 72 \text { hours of admission, } \\
\text { titer } \geq 1350\end{array}$} \\
\hline & $\frac{\text { Total }}{(N=224)}$ & $\frac{\text { Control }}{(n=112)}$ & $\frac{\text { Case }}{(n=112)}$ & $P$ value & $\frac{\text { Total }}{(N=92)}$ & $\frac{\text { Control }}{(n=61)}$ & $\frac{\text { Case }}{(n=31)}$ & $P$ value & $\frac{\text { Total }}{(N=243)}$ & $\frac{\text { Control }}{(n=158)}$ & $\frac{\text { Case }}{(n=85)}$ & $P$ value \\
\hline Age, years & & & & 0.08 & & & & 0.73 & & & & 0.12 \\
\hline$<30$ & $16(7.1)$ & $5(4.5)$ & $11(9.8)$ & & $3(3.3)$ & $2(3.3)$ & $1(3.2)$ & & $16(6.6)$ & $10(6.3)$ & $6(7.1)$ & \\
\hline $30-39$ & $34(15.2)$ & $15(13.4)$ & $19(17.0)$ & & $10(10.9)$ & $6(9.8)$ & $4(12.9)$ & & $34(14.0)$ & $18(11.4)$ & $16(18.8)$ & \\
\hline $60-69$ & $53(23.7)$ & $33(29.5)$ & $20(17.9)$ & & $26(28.3)$ & $18(29.5)$ & $8(25.8)$ & & $57(23.5)$ & $43(27.2)$ & $14(16.5)$ & \\
\hline $70-79$ & $16(7.1)$ & $10(8.9)$ & $6(5.4)$ & & $8(8.7)$ & $4(6.6)$ & $4(12.9)$ & & $20(8.2)$ & $15(9.5)$ & $5(5.9)$ & \\
\hline$\geq 80$ & $3(1.3)$ & $3(2.7)$ & $0(0.0)$ & & $1(1.1)$ & $0(0.0)$ & $1(3.2)$ & & $2(0.8)$ & $2(1.3)$ & $0(0.0)$ & \\
\hline Sex & & & & 0.78 & & & & 1.00 & & & & 0.12 \\
\hline Female & $88(39.3)$ & $45(40.2)$ & $43(38.4)$ & & $39(42.4)$ & $26(42.6)$ & $13(41.9)$ & & 99 (40.7) & $70(44.3)$ & $29(34.1)$ & \\
\hline Male & $136(60.7)$ & $67(59.8)$ & 69 (61.6) & & $53(57.6)$ & $35(57.4)$ & $18(58.1)$ & & $144(59.3)$ & $88(55.7)$ & $56(65.9)$ & \\
\hline Other & $9(4.0)$ & $1(0.9)$ & $8(7.1)$ & & $2(2.2)$ & $1(1.6)$ & $1(3.2)$ & & $9(3.7)$ & $3(1.9)$ & $6(7.1)$ & \\
\hline Unknown & $7(3.1)$ & $2(1.8)$ & $5(4.5)$ & & $0(0.0)$ & $0(0.0)$ & $0(0.0)$ & & $5(2.1)$ & $1(0.6)$ & $4(4.7)$ & \\
\hline Ethnicity & & & & 0.04 & & & & 1.00 & & & & 0.01 \\
\hline Not Hispanic & $113(50.4)$ & $66(58.9)$ & $47(42.0)$ & & $55(59.8)$ & $36(59.0)$ & $19(61.3)$ & & $116(47.7)$ & $86(54.4)$ & $30(35.3)$ & \\
\hline Hispanic & $109(48.7)$ & $45(40.2)$ & $64(57.1)$ & & $36(39.1)$ & $24(39.3)$ & $12(38.7)$ & & $123(50.6)$ & 69 (43.7) & $54(63.5)$ & \\
\hline Unknown & $2(0.9)$ & $1(0.9)$ & $1(0.9)$ & & $1(1.1)$ & $1(1.6)$ & $0(0.0)$ & & $4(1.6)$ & $3(1.9)$ & $1(1.2)$ & \\
\hline $\begin{array}{l}\text { Body mass index, } \\
\qquad \mathrm{kg} / \mathrm{m}^{2}\end{array}$ & & & & 0.34 & & & & 0.66 & & & & 0.89 \\
\hline$<30$ & $89(39.7)$ & $48(42.9)$ & $41(36.6)$ & & $41(44.6)$ & $26(42.6)$ & $15(48.4)$ & & $90(37.0)$ & $59(37.3)$ & $31(36.5)$ & \\
\hline$\geq 30$ & $135(60.3)$ & $64(57.1)$ & $71(63.4)$ & & $51(55.4)$ & $35(57.4)$ & $16(51.6)$ & & $153(63.0)$ & $99(62.7)$ & $54(63.5)$ & \\
\hline Hypertension & & & & 1.00 & & & & 0.33 & & & & 0.24 \\
\hline No & $122(54.5)$ & $61(54.5)$ & $61(54.5)$ & & $41(44.6)$ & $25(41.0)$ & $16(51.6)$ & & $119(49.0)$ & $73(46.2)$ & $46(54.1)$ & \\
\hline Yes & $102(45.5)$ & $51(45.5)$ & $51(45.5)$ & & $51(55.4)$ & $36(59.0)$ & $15(48.4)$ & & $124(51.0)$ & $85(53.8)$ & $39(45.9)$ & \\
\hline Yes & $22(9.8)$ & $13(11.6)$ & $9(8.0)$ & & $13(14.1)$ & $8(13.1)$ & $5(16.1)$ & & 29 (11.9) & $21(13.3)$ & $8(9.4)$ & \\
\hline Hyperlipidemia & & & & 0.55 & & & & 0.96 & & & & 0.82 \\
\hline No & $162(72.3)$ & $79(70.5)$ & $83(74.1)$ & & $59(64.1)$ & $39(63.9)$ & $20(64.5)$ & & $178(73.3)$ & $115(72.8)$ & $63(74.1)$ & \\
\hline Yes & $62(27.7)$ & $33(29.5)$ & $29(25.9)$ & & $33(35.9)$ & $22(36.1)$ & $11(35.5)$ & & 65 (26.7) & $43(27.2)$ & $22(25.9)$ & \\
\hline Coronary disease & & & & 0.18 & & & & 0.74 & & & & 0.41 \\
\hline No & $209(93.3)$ & $102(91.1)$ & $107(95.5)$ & & $81(88.0)$ & $53(86.9)$ & $28(90.3)$ & & $224(92.2)$ & $144(91.1)$ & $80(94.1)$ & \\
\hline Yes & $15(6.7)$ & $10(8.9)$ & $5(4.5)$ & & $11(12.0)$ & $8(13.1)$ & $3(9.7)$ & & $19(7.8)$ & $14(8.9)$ & $5(5.9)$ & \\
\hline $\begin{array}{l}\text { Baseline ventilation } \\
\text { status (within } 28 \\
\text { hours of } \\
\text { admission) }\end{array}$ & & & & 0.65 & & & & 0.07 & & & & 0.80 \\
\hline Room air & $9(4.0)$ & $3(2.7)$ & $6(5.4)$ & & $4(4.3)$ & $1(1.6)$ & $3(9.7)$ & & $12(4.9)$ & $7(4.4)$ & $5(5.9)$ & \\
\hline $\begin{array}{l}\text { Supplemental } \\
\text { oxygen }\end{array}$ & $189(84.4)$ & $96(85.7)$ & $93(83.0)$ & & $68(73.9)$ & $44(72.1)$ & $24(77.4)$ & & $210(86.4)$ & $138(87.3)$ & $72(84.7)$ & \\
\hline $\begin{array}{l}\text { Mechanical } \\
\text { ventilation }\end{array}$ & $26(11.6)$ & $13(11.6)$ & $13(11.6)$ & & $20(21.7)$ & $16(26.2)$ & $4(12.9)$ & & $21(8.6)$ & $13(8.2)$ & $8(9.4)$ & \\
\hline $\begin{array}{l}\text { Ventilation status at } \\
\text { day } 0\end{array}$ & & & & 1.00 & & & & 1.00 & & & & 0.42 \\
\hline Room air & $20(8.9)$ & $10(8.9)$ & $10(8.9)$ & & $9(9.8)$ & $6(9.8)$ & $3(9.7)$ & & $30(12.3)$ & $20(12.7)$ & $10(11.8)$ & \\
\hline Low flow & $140(62.5)$ & $70(62.5)$ & $70(62.5)$ & & $39(42.4)$ & $26(42.6)$ & $13(41.9)$ & & 173 (71.2) & $116(73.4)$ & $57(67.1)$ & \\
\hline High flow/NIPPV & $40(17.9)$ & $20(17.9)$ & $20(17.9)$ & & 18 (19.6) & $12(19.7)$ & $6(19.4)$ & & $23(9.5)$ & $11(7.0)$ & $12(14.1)$ & \\
\hline $\begin{array}{l}\text { Mechanical } \\
\text { ventilation }\end{array}$ & $22(9.8)$ & $11(9.8)$ & $11(9.8)$ & & $24(26.1)$ & $16(26.2)$ & $8(25.8)$ & & $16(6.6)$ & $10(6.3)$ & $6(7.1)$ & \\
\hline
\end{tabular}




\begin{tabular}{|c|c|c|c|c|c|c|c|c|c|c|c|c|}
\hline \multirow{2}{*}{ Characteristic } & \multicolumn{4}{|c|}{$\begin{array}{l}\text { Secondary matched, transfused } \\
\text { within } 72 \text { hours of admission }\end{array}$} & \multicolumn{4}{|c|}{$\begin{array}{l}\text { Secondary matched, transfused } \\
>72 \text { hours after admission }\end{array}$} & \multicolumn{4}{|c|}{$\begin{array}{l}\text { Secondary matched, transfused } \\
\text { within } 72 \text { hours of admission, } \\
\text { titer } \geq 1350\end{array}$} \\
\hline & $\frac{\text { Total }}{(N=224)}$ & $\frac{\text { Control }}{(n=112)}$ & $\frac{\text { Case }}{(n=112)}$ & $P$ value & $\frac{\text { Total }}{(N=92)}$ & $\frac{\text { Control }}{(n=61)}$ & $\frac{\text { Case }}{(n=31)}$ & $P$ value & $\frac{\text { Total }}{(N=243)}$ & $\frac{\text { Control }}{(n=158)}$ & $\frac{\text { Case }}{(n=85)}$ & $P$ value \\
\hline ECMO & $2(0.9)$ & $1(0.9)$ & $1(0.9)$ & & $2(2.2)$ & $1(1.6)$ & $1(3.2)$ & & $1(0.4)$ & $1(0.6)$ & $0(0.0)$ & \\
\hline Deceased & $0(0.0)$ & $0(0.0)$ & $0(0.0)$ & & $0(0.0)$ & $0(0.0)$ & $0(0.0)$ & & $0(0.0)$ & $0(0.0)$ & $0(0.0)$ & \\
\hline$A B 0$ blood group & & & & $<0.001$ & & & & 0.002 & & & & $<0.001$ \\
\hline$A B$ & $5(2.6)$ & $2(2.5)$ & $3(2.7)$ & & $2(2.6)$ & $1(2.2)$ & $1(3.2)$ & & $4(2.1)$ & $2(1.8)$ & $2(2.4)$ & \\
\hline 0 & $108(56.0)$ & $45(55.6)$ & $63(56.3)$ & & $44(57.1)$ & 24 (52.2) & $20(64.5)$ & & $106(54.6)$ & $59(54.1)$ & $47(55.3)$ & \\
\hline Rh blood group & & & & $<0.001$ & & & & $<0.001$ & & & & $<0.001$ \\
\hline Negative & $19(8.5)$ & $6(5.4)$ & 13 (11.6) & & $8(8.7)$ & $7(11.5)$ & $1(3.2)$ & & $16(6.6)$ & $6(3.8)$ & $10(11.8)$ & \\
\hline Positive & $174(77.7)$ & $75(67.0)$ & $99(88.4)$ & & $69(75.0)$ & $39(63.9)$ & $30(96.8)$ & & $178(73.3)$ & $103(65.2)$ & 75 (88.2) & \\
\hline Unknown & $31(13.8)$ & $31(27.7)$ & $0(0.0)$ & & $15(16.3)$ & $15(24.6)$ & $0(0.0)$ & & $49(20.2)$ & $49(31.0)$ & $0(0.0)$ & \\
\hline $\begin{array}{l}\text { Ferritin at day } 0, \\
\mathrm{ng} / \mathrm{mL}\end{array}$ & $\begin{array}{l}702.0 \\
(301.0- \\
1280.0)\end{array}$ & $\begin{array}{l}613.0 \\
\quad(272.0- \\
1220.0)\end{array}$ & $\begin{array}{l}735.5 \\
(349.5- \\
1305.5)\end{array}$ & 0.43 & $\begin{array}{l}999.0 \\
\quad(461.0- \\
1585.0)\end{array}$ & $\begin{array}{l}897.0 \\
(332.0- \\
1360.5)\end{array}$ & $\begin{array}{c}1034.0 \\
(696.0- \\
2118.0)\end{array}$ & 0.06 & $\begin{array}{l}677.5 \\
(302.0- \\
1309.0)\end{array}$ & $\begin{array}{l}615.0 \\
(302.0- \\
1366.0)\end{array}$ & $\begin{array}{l}702.0 \\
\quad(314.0- \\
1265.0)\end{array}$ & 0.92 \\
\hline $\begin{array}{l}\text { Fibrinogen at day } 0, \\
\mathrm{mg} / \mathrm{dL}\end{array}$ & $\begin{array}{l}620.0 \\
\quad(504.0- \\
719.0)\end{array}$ & $\begin{array}{l}609.0 \\
\quad(485.0- \\
705.0)\end{array}$ & $\begin{array}{l}623.0 \\
\quad(527.0- \\
730.0)\end{array}$ & 0.27 & $\begin{array}{l}651.0 \\
\quad(503.0- \\
756.0)\end{array}$ & $\begin{array}{l}640.5 \\
(511.5- \\
752.0)\end{array}$ & $\begin{array}{l}695.0 \\
\quad(503.0- \\
802.0)\end{array}$ & 0.62 & $\begin{array}{l}641.0 \\
\quad(516.0- \\
740.0)\end{array}$ & $\begin{array}{l}630.0 \\
\quad(515.0- \\
756.0)\end{array}$ & $\begin{array}{l}642.5 \\
\quad(516.0- \\
732.0)\end{array}$ & 0.98 \\
\hline $\begin{array}{l}\text { D-dimer at day } 0, \\
\mu \mathrm{g} / \mathrm{mL} \mathrm{FEU}\end{array}$ & $\begin{array}{l}0.9 \\
\quad(0.6- \\
1.9)\end{array}$ & $\begin{array}{l}1.0 \\
\quad(0.7- \\
2.3)\end{array}$ & $\begin{array}{l}0.8 \\
\quad(0.5- \\
1.6)\end{array}$ & 0.02 & $\begin{array}{l}1.2 \\
\quad(0.8- \\
3.2)\end{array}$ & $\begin{array}{l}1.2 \\
\quad(0.7- \\
3.0)\end{array}$ & $\begin{array}{l}1.2 \\
\quad(0.8- \\
3.6)\end{array}$ & 0.74 & $\begin{array}{l}0.9 \\
\quad(0.6- \\
1.6)\end{array}$ & $\begin{array}{l}0.9 \\
\quad(0.6- \\
1.6)\end{array}$ & $\begin{array}{l}0.8 \\
\quad(0.5- \\
1.6)\end{array}$ & 0.10 \\
\hline \multicolumn{13}{|l|}{$\begin{array}{l}\text { Concomitant } \\
\text { medication }\end{array}$} \\
\hline Ribavirin & $35(15.6)$ & $25(22.3)$ & $10(8.9)$ & 0.01 & $31(33.7)$ & $20(32.8)$ & $11(35.5)$ & 0.80 & 28 (11.5) & $27(17.1)$ & $1(1.2)$ & $<0.001$ \\
\hline Tocilizumab & $90(40.2)$ & $36(32.1)$ & $54(48.2)$ & 0.01 & $40(43.5)$ & $20(32.8)$ & $20(64.5)$ & 0.004 & $76(31.3)$ & $38(24.1)$ & $38(44.7)$ & $<0.001$ \\
\hline
\end{tabular}

Values are in median (IQR) for continuous variables and $n(\%)$ for categorical variables. Difference between groups was compared using the Wilcoxon ranksum test for continuous variables and $\chi^{2}$ or Fisher exact tests for categorical variables, as appropriate.

ECM0, extracorporeal membrane oxygenation; FEU, fibrinogen equivalent units; IQR, interquartile range; NIPPV, noninvasive positive-pressure ventilation.

\section{Convalescent Plasma Donors}

The study protocols for convalescent plasma collection have been described. ${ }^{19,25}$ Briefly, convalescent plasma was obtained by apheresis and processed by standard blood banking protocols under Houston Methodist human subjects protocol PRO00025121. US Food and Drug Administration recommendations for COVID-19 convalescent plasma donor collection were followed (https://www.fda.gov/vaccinesblood-biologics/investigational-new-drug-ind-or-device-exe mption-ide-process-cber/recommendations-investigationalcovid-19-convalescent-plasma\#patienteligibility, last accessed July 11, 2020). Each donor had recovered from laboratoryconfirmed SARS-CoV-2 infection based on a positive RTPCR test. All plasma was donated by recovered and healthy COVID-19 patients who had been asymptomatic for $>14$ days. Donors were aged between 18 and 65 years, and all provided written informed consent and tested negative for SARS-CoV-2 at the time of plasmapheresis. If eligible according to standard blood donor criteria, donors were enrolled in a frequent plasmapheresis program. Donors were documented to be negative for anti-human leukocyte antigen antibodies, hepatitis B, hepatitis C, HIV, human T-cell leukemia virus I/II, Chagas disease, West Nile virus, Zika virus, and syphilis, per standard blood banking practices.

\section{Convalescent Plasma Titer Assessment (SARS-CoV-2 Enzyme-Linked Immunosorbent Assay)}

Convalescent plasma titer assessment was performed as recently described. ${ }^{19,25}$ Briefly, purified recombinant 
ectodomain, composed of amino acid residues 1 to 1208 , and/or RBD, composed of amino acids 319 to 591, of the SARS-CoV-2 spike protein (https://www.ncbi.nlm.nih. gov/nuccore; GenBank accession number MN908947) were coated onto microtiter plates. Human monoclonal antibody CR3022 that targets the RBD of SARSassociated coronavirus was used as a positive control. ${ }^{27}$ Negative serum control was included on each microtiter plate. Serial dilutions of serum were added, incubated for 1 hour, washed, incubated with goat anti-human IgG Fab horseradish peroxidase (Sigma, St. Louis, MO; A0293), and washed. Enzyme-linked immunosorbent assay substrate (1-step Ultra TMB; Thermo Fisher Scientific, Waltham, MA; catalog number 34028) was added, plates were developed until the highest dilution reached the saturation point, and the reaction was stopped with sulfuric acid. Plates were read at an absorbance of $450 \mathrm{~nm}$.

\section{Statistical Analysis}

Patient characteristics and outcomes were reported as frequencies and proportions for categorical variables, and median and interquartile range or mean and SD for continuous variables, as appropriate. Differences between groups (eg, transfused versus non-transfused) were determined by the Wilcoxon rank-sum test or $t$-test for continuous variables, and $\chi^{2}$ or Fisher exact tests for categorical variables, as appropriate.

Only patients who met a 28-day outcome, defined as having outcome data available 28 days post-transfusion (cases) and 28 days postadmission (controls), were analyzed. Patients discharged before day 28 were presumed to be on room air after discharge, unless otherwise noted in the electronic health record. Baseline patient characteristics for all COVID-19 patients and for patients who met a 28day outcome are shown in Supplemental Table S1.

A one-to-many nearest neighbor propensity score matching without replacement was conducted using an initial ratio of case/control $=1: 3$ and caliper of 1 between patients having plasma transfusion (cases) versus patients who did not have plasma transfusion (controls). The primary matching criteria included age (categorical, $<30,30$ to 39 , 40 to 49,50 to 59,60 to 69,70 to 79 , and $\geq 80$ years), sex, body mass index $\left(<30 / \geq 30 \mathrm{~kg} / \mathrm{m}^{2}\right)$, diabetes, hypertension, chronic pulmonary disease, chronic kidney disease, hyperlipidemia, coronary disease, and baseline ventilation requirement within 48 hours from admission. A secondary propensity score matching the ratio of case/control of either $1: 2$ or $1: 1$ and caliper $<1$ was conducted on the basis of the ventilation status at day 0 , which was defined as the day of transfusion for cases and the corresponding day in the hospitalization course for controls ${ }^{28}$ (Supplemental Table S2).

Variability in the timing of transfusion and the titer of plasma allowed for analysis in specific matched cohorts. The following prespecified sub-groups of transfused patients were also identified and matched with available controls: patients transfused with plasma within 72 hours of admission; patients who were transfused $>72$ hours after admission; and patients transfused within 72 hours of admission with an anti-RBD IgG titer $\geq 1: 1350$ (Table 1). A titer of $\geq 1: 1350$ was chosen on the basis of previous work that demonstrated that an anti-RBD IgG 1:1350 indicated an $80 \%$ probability of viral neutralization titer $\geq 1: 160$, the recommended viral neutralization cutoff for COVID-19 convalescent plasma for therapeutic purposes. ${ }^{25}$ Cohortspecific propensity score matching runs were executed for individual cohorts (eg, plasma with all anti-RBD IgG titers, titer $\geq 1: 1350$, and titer $<1: 1350$ ) to ensure that a balance of all matching criteria was kept within the individual cohorts. The cohort-specific secondary propensity score matches started with a case/control ratio of 1:2 to maximize precision. The case/control ratio decreased to 1:1 for some cohorts when there were not enough matched controls available. A subanalysis comparing outcomes in subgroups of transfused patients with each other rather than with matched controls was also conducted. One subgroup was added based on post-hoc assessment of the matched data: patients transfused after 72 hours of admission with plasma with an anti-RBD titer $<1: 1350$.

The primary outcome, mortality within 28 days post-day 0 , is depicted by the Kaplan-Meier curves. Differences between groups were compared using the log-rank test. Cox proportional hazards modeling (with clustered sandwich estimator option for the matched cluster in the propensity-matched cohorts) was performed to determine the characteristics associated with the overall mortality within 28 days. Variables for the multivariable models were selected on the basis of potential clinical relevance and by the Stata Lasso technique with the cross-validation selection option. ${ }^{29,30}$

Generalized linear model and multinomial logistic regression with cluster variance estimator were also used to evaluate several exploratory end points. The evaluated covariates included: supplemental oxygen requirements (room air, low-flow oxygen delivery, high-flow oxygen delivery, noninvasive positive pressure ventilation, mechanical ventilation, extracorporeal membrane oxygenation, or death) at day 7 , day 14 , and day 28 post-transfusion; clinical improvement relative to day 0 ; intensive care unit stay requirement; intensive care unit length of stay; mechanical ventilation requirement; length of mechanical ventilation requirement; length of supplemental oxygen requirement; and inflammatory marker levels (IL-6, Creactive protein, ferritin, fibrinogen, and D-dimer) at day 7 . Clinical improvement relative to day 0 was defined as a onepoint improvement in ordinal scale [1, discharged (alive); 2 , hospitalized, not requiring supplemental oxygen but requiring ongoing medical care (for COVID-19 or otherwise); 3, hospitalized, requiring low-flow supplemental oxygen; 4, hospitalized, on noninvasive ventilation or highflow oxygen devices; 5 , hospitalized and on invasive mechanical ventilation or extracorporeal membrane 
oxygenation; and 6, death]. All analyses were performed with Stata version 16.1 (StataCorp LLC, College Station, TX). $P \leq 0.05$ was considered significant.

\section{Results}

\section{Study Population and Baseline Characteristics}

In this study, data from 2724 admitted COVID-19 patients were available for analysis, 316 of whom were transfused with COVID-19 convalescent plasma (Figure 1). Baseline characteristics of all admitted COVID-19 patients are shown (Supplemental Table S1). Relative to non-transfused patients, transfused patients generally were younger, were predominantly male, had a higher body mass index, had lower rates of comorbidities (specifically, chronic pulmonary disease, chronic kidney disease, hyperlipidemia, coronary disease, and hypertension, but not diabetes), had a higher requirement for supplemental oxygen, and had higher inflammatory marker concentrations. Use of steroids, azithromycin, and tocilizumab was more common among the transfused cohort, but use of remdesivir was not. Most transfused patients $(242 / 316 ; 76 \%)$ received only one unit of COVID-19 convalescent plasma. Most patients received an initial or sole unit of convalescent plasma with anti-RBD IgG titer of $\geq 1: 1350$ (284/316; 90\%); 22 patients received an initial or sole unit of convalescent plasma with an antiRBD IgG titer $>1: 150$ but $<1: 1350 ; 8$ patients received an initial or sole unit of convalescent plasma with anti-RBD IgG titer of $<1: 150$; and for 2 patients, a sample for assessment of the anti-RBD IgG titer was not available. For patients who received a second unit of convalescent plasma, $70(70 / 74 ; 95 \%)$ received a second unit with an anti-RBD IgG titer $\geq 1: 1350$, and $4(4 / 74 ; 5 \%)$ patients received a second unit with an anti-RBD IgG titer $>1: 150$ but $<1: 1350$.

Initial propensity score matching yielded a study population of 145 transfused patients and 435 matched controls. This primary propensity score matching, including requirement for supplemental oxygen or mechanical ventilation within 48 hours of admission, yielded a significant difference between the case and control cohort with respect to ventilation status at day 0: $35 \%$ of controls were on room air at day 0 compared with only $9 \%$ of cases. Table 1 and Supplemental Table S2 present the baseline characteristics of cohorts after secondary matching for ventilation status at day 0 , which were balanced in all matching criteria. After this secondary matching, there were 136 transfused patients matched to 251 controls (Figure 1).

\section{Outcomes}

A decreased probability of death within 28 days post-day 0 was observed in the transfused cohort relative to propensity score-matched controls, although the difference did not reach statistical significance (Figure 2A). We hypothesized that transfusion early in hospitalization is more

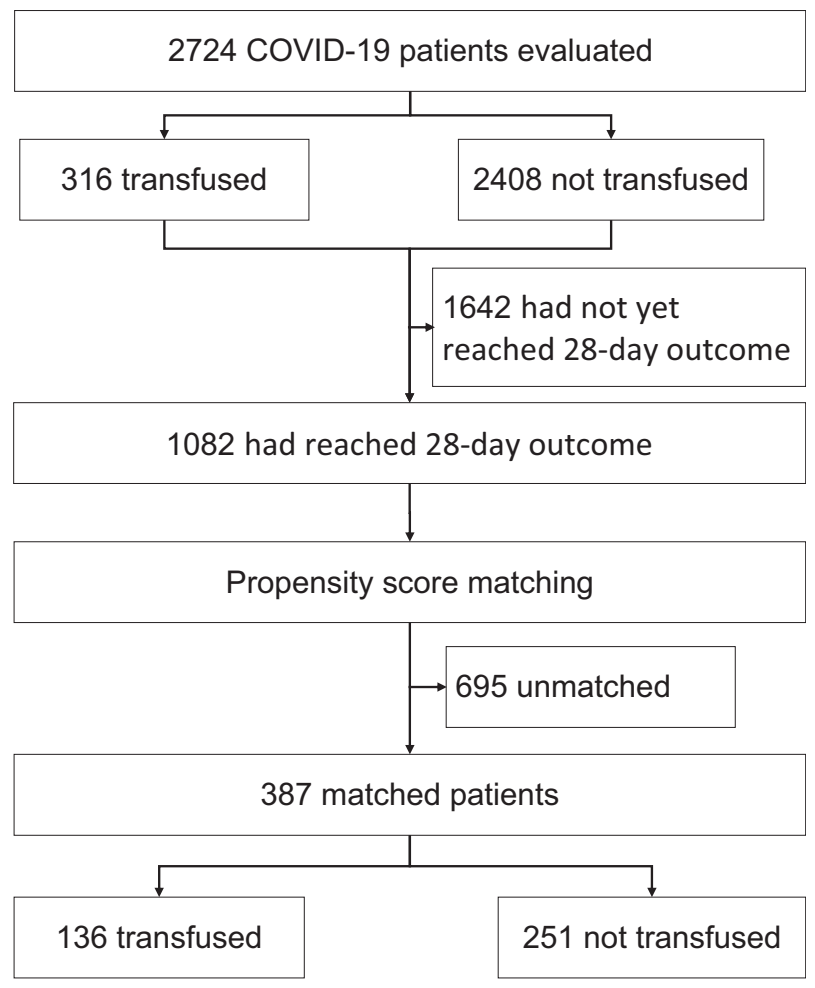

Figure 1 Flowchart of the study population. Propensity score matching was based on patient age (categorical, per 10 years), sex, body mass index (categorical, $\pm 30 \mathrm{~kg} / \mathrm{m}^{2}$ ), diabetes, hypertension, chronic pulmonary disease, chronic kidney disease, hyperlipidemia, and coronary disease, and baseline ventilation status within 48 hours of admission (room air, supplemental oxygen, and mechanical ventilation). After establishing the first propensity score-matched cohort and obtaining day 0 for controls, a second match was run between cases and controls based on the ventilation status at day 0. COVID-19, coronavirus disease 2019.

beneficial than transfusion later. Consistent with the hypothesis, relative to matched controls, patients transfused within 72 hours of hospital admission had decreased mortality within 28 days, whereas patients transfused after 72 hours of hospital admission did not. The decreased mortality was improved and reached significance $(P=0.047)$ when only patients who received a plasma transfusion with an anti-RBD IgG titer of $\geq 1: 1350$ (high titer) within 72 hours of hospital admission were considered (Figure 2, B-D).

Point estimates of the various outcomes confirm these findings (Table 2). Compared with patients who received plasma transfusion within 72 hours of hospitalization, control patients were more likely to have a higher risk of mortality within 28 days [relative risk (RR), 3.50; 95\% CI, $0.87-14.08 ; P=0.08]$ and overall mortality with no time constraints (RR, 3.33; 95\% CI, 1.01-10.98; $P=0.048$ ). Risk of overall mortality, and mortality within 28 days in non-transfusion patients, was significantly higher when compared with patients who received plasma transfusion with an anti-RBD IgG titer of $\geq 1: 1350$ (high titer) within 72 hours of hospital admission (RR, 7.53; 95\% CI, $1.12-50.46 ; P=0.04$; and RR, 5.92; 95\% CI, 0.90-38.84; 

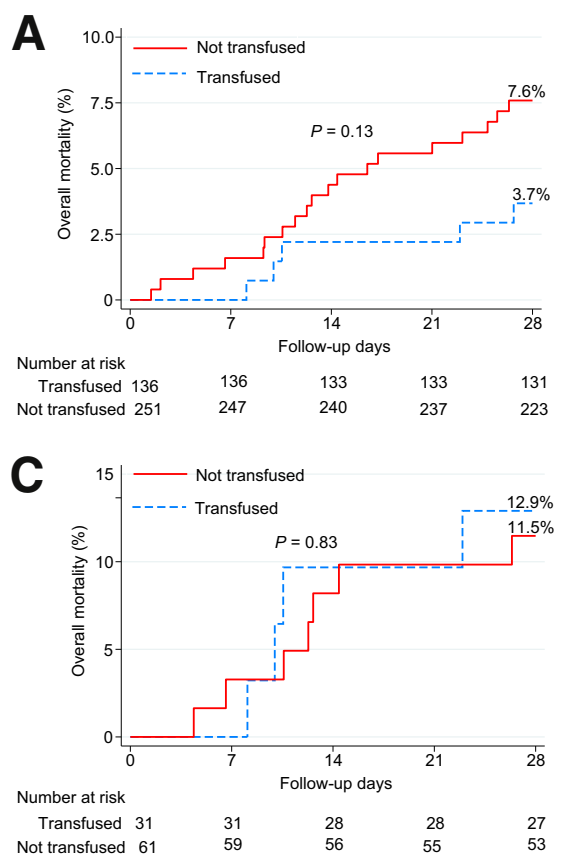
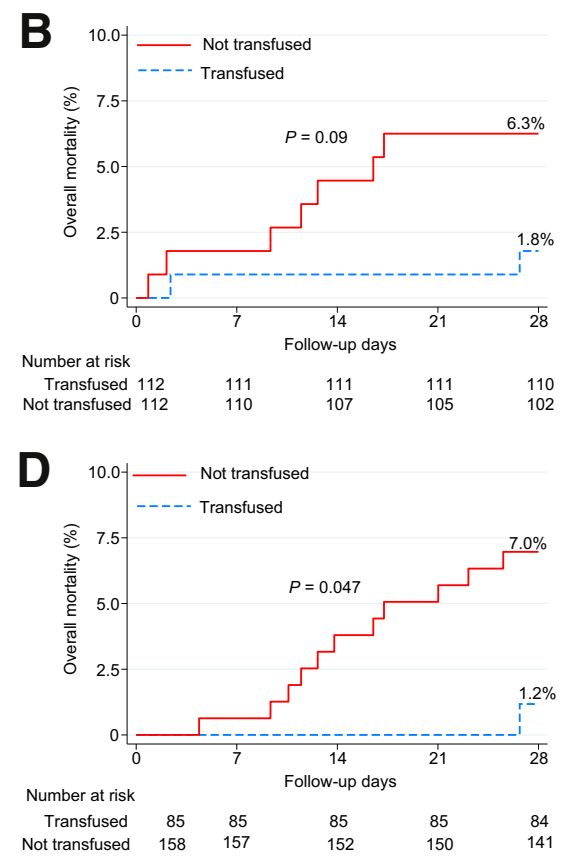

Figure 2 Kaplan-Meier curves for mortality within 28 days post-day 0 for secondary matched cohorts. A: All secondary matched patients. B: Secondary matched patients transfused within 72 hours of admission. C: Secondary matched patients transfused $>72$ hours after admission. D: Secondary matched patients transfused within 72 hours of admission with plasma with anti-receptor binding domain IgG titer $\geq 1: 1350$.
$P=0.06$, respectively). There was no reduction in the risk of mortality within 28 days or mortality with no time constraints when patients were transfused $>72$ hours after admission (RR, 0.89; 95\% CI, 0.24-3.30; $P=0.86$; and RR, 0.81; 95\% CI, 0.25-2.69; $P=0.74$, respectively).

Additional outcomes assessed between matched cohorts are shown in Table 2. Secondary matched patients transfused within 72 hours of admission with plasma with an anti-RBD IgG titer $\geq 1: 1350$ had decreased overall mortality with no time constraints, decreased intensive care unit requirement post-day 0 , and increased clinical improvement at day 14 and day 28, despite a higher proportion of patients being on high-intensity oxygen therapy (high flow/noninvasive positive-pressure ventilation) at day 0 and increased need for supplemental oxygen post-day 0 .

A subanalysis comparing outcomes in subgroups of transfused patients rather than with matched controls showed findings consistent with transfusion earlier in the hospital stay, with high titer convalescent plasma being more beneficial, although the number of events (mortality) was small in these subgroups (Supplemental Figure S1 and Supplemental Tables S3 and S4). Specifically, compared with patients who received plasma transfusion within 72 hours, patients who received plasma transfusion $>72$ hours after admission had a significantly higher risk of mortality within 28 days (RR, 7.19; 95\% CI, 1.38-37.48; $P=0.02$ ) and of mortality analyzed with no time constraints (RR, 5.99; 95\% CI, $1.51-23.73 ; P=0.01)$. Relative to patients transfused within 72 hours of admission with anti-RBD IgG plasma with a titer $\geq 1: 1350$, patients transfused $>72$ hours after admission with anti-RBD IgG plasma with a titer $<1: 1350$ had a significantly higher risk of mortality within 28 days (RR, 9.4; 95\% CI,
1.48-59.69; $P=0.02)$ and of mortality with no time constraints (RR, 14.1; 95\% CI, 2.66-74.61; $P=0.02)$.

\section{Univariate and Multivariate Analysis}

In propensity score-matched patients, univariate analysis indicated that factors associated with higher mortality were advanced age, hypertension, diabetes, chronic kidney disease, coronary disease, higher IL-6, higher D-dimer, and use of any steroid, ribavirin, or tocilizumab. Multivariate analysis, in a model excluding variables that were used in the propensity score match, showed that the risk of mortality within 28 days was increased in patients who were not transfused with convalescent plasma (regardless of titer or timing), with a trend toward significance (adjusted hazard ratio, 2.73; 95\% CI, $1-7.48 ; P=0.051$ ) (Supplemental Tables S5 and S6). Multivariate analysis is not yet possible with the various subanalysis cohorts, including those patients transfused with high-titer plasma within 72 hours of admission, due to low number of events (deaths), overall.

\section{Discussion}

Tens of thousands of COVID-19 patients in the United States have now been transfused with convalescent plasma. This treatment has been documented to be safe; however, few controlled studies that assess efficacy have been published. Herein, the results of interim analysis of a prospective, ongoing matched study are provided. In aggregate, the data suggest that transfusion of high anti-RBD IgG titer 
convalescent plasma early in the hospital course significantly reduces mortality. Several lines of evidence support this conclusion, including survival analysis of specific cohorts of transfused patients relative to matched controls, point estimates from generalized linear model and multinomial logistic regression, multivariate analysis, and comparisons of outcomes in different cohorts of transfused patients.

These results are also consistent with previous studies. ${ }^{28,31-34}$ A recent randomized clinical trial of 101 cases and controls examined clinical improvement up to 28 days post-transfusion, and found that $52 \%$ of plasma recipients had improvement versus $43.1 \%$ of the control group. ${ }^{34}$ Although no significant difference in 28-day mortality was observed, the conclusions were limited by early termination of the study because of low enrollment as the regional outbreak waned. ${ }^{34}$ A second study examined efficacy in 39 patients compared with retrospectively matched controls. ${ }^{28}$ The results showed that patients receiving convalescent plasma therapy had improved survival and supplementary oxygen requirements at day 14 post-transfusion compared with non-transfused controls. In a smaller study by Hegerova et al, ${ }^{33} 20$ COVID-19 patients who received convalescent plasma had improved laboratory and respiratory parameters compared with matched controls, and in both matched control studies, nonintubated patients benefited more from transfusion than intubated patients. ${ }^{28,33}$

Early in the pandemic, convalescent plasma was administered under emergency use protocols without knowledge of donor plasma antibody or virus neutralization titers. For donor plasma, the US Food and Drug Administration has recommended a virus neutralization titer of at least 1:160 (https://www.fda.gov/vaccines-blood-biologics/investigatio nal-new-drug-ind-or-device-exemption-ide-process-cber/ recommendations-investigational-covid-19-convalescentplasma\#patienteligibility, last access July 11, 2020). It was recently demonstrated that the probability of having a virus neutralization titer $\geq 160$ was $>80 \%$ with plasma anti-RBD or anti-ectodomain titers of $\geq 1: 1350$. $^{25}$ Thus, when these data were generated, and as the pool of high titer donors grew, this study changed to transfusing only plasma with at least this titer of anti-RBD IgG. This evolving approach permitted the retrospective comparison of outcomes in different cohorts of patients with respect to the titer anti-RBD IgG of plasma received. This finding that high anti-RBD IgG titer plasma is more efficacious is consistent with work showing that the RBD of the spike protein is the important region for angiotensin-converting enzyme 2 receptor binding and host entry by SARS-CoV-2, ${ }^{35,36}$ and that anti-RBD IgG titer correlates with in vitro virus neutralization. ${ }^{25}$

Passive antibody therapy is thought to have higher efficacy when administered early in the course of an infectious disease. ${ }^{37}$ Analysis of 80 patients in Hong Kong during the 2003 SARS epidemic showed a significant benefit to earlier administration of convalescent plasma. Patients given plasma within 14 days of illness had a higher 22-day discharge rate than those given plasma beyond 14 days of symptoms $(P=0.001) .{ }^{10}$ Data from 20,000 transfused COVID-19 patients support the notion that transfusion earlier in the clinical course is more beneficial. ${ }^{38} \mathrm{~A}$ recent study from the Netherlands showed that at the time of transfusion (median, 10 days post-symptom onset), many $(80 \%)$ of the COVID-19 patients already had detectable neutralizing antibody titers, although the titer of transfused plasma units was higher than that found in recipients ${ }^{32}$; the study was discontinued as a result of this finding. In addition, analysis of nine patients (five not receiving convalescent plasma) with low titers on day $1(<1: 160)$ showed that all nine had a fourfold increase in titers by day 7 . The authors concluded that patients with recent symptom onset should be targeted for convalescent plasma therapy. ${ }^{28,33}$ Consistent with these observations, in our analysis, patients transfused with high-titer plasma within 72 hours of admission saw the most benefit. The finding of a trend toward worse ventilation status at day 7 post-transfusion in those patients transfused $>72$ hours after admission relative to matched controls (Table 2) may indicate that the risk/ benefit ratio of convalescent plasma is different later in the course of the disease.

This analysis has implications for collection, use, and study of COVID-19 convalescent plasma. In our experience, many requests for convalescent plasma are for patients who have already received other therapies and are late in their disease course. Although in the aggregate convalescent plasma is a safe therapy, these data argue that careful consideration should be given to the potential risks and benefits given the clinical context, as transfusion may only be beneficial early in the clinical course. Substantial efforts are underway in the United States to collect COVID-19 convalescent plasma. These data indicate that assessment of antibody titer through a viral neutralization assay or a surrogate thereof is likely to identify donors and plasma units that are most likely to be beneficial. Clinical trials are ongoing in many centers, and the data presented herein may inform the assessment of equipoise in their design and conduct. ${ }^{39-42}$

This study has several limitations. First, although the patient sample size is large, it is an interim analysis of an ongoing study. Second, it is not a randomized, controlled trial, but rather a propensity score-matched analysis. Although every effort was made to control for important covariates, it is not yet possible to match for all potentially relevant covariates, given the sample sizes. Because race, ethnicity, inflammatory markers, ABO type, and concomitant medications were not included in the match parameters, there were statistically significant differences in these characteristics among the various cohorts. The background standard of care for COVID-19 is evolving as new data emerge. In this matched cohort of patients transfused with high-titer plasma within 72 hours of admission, there were significant differences in the use of prednisone (higher in non-transfused patients), hydroxychloroquine (higher in 


\begin{tabular}{|c|c|c|c|c|c|c|c|c|c|c|c|c|c|c|c|}
\hline \multirow[b]{3}{*}{ Variable } & \multicolumn{5}{|c|}{ Secondary matched, transfused within 72 hours of admission } & \multicolumn{5}{|c|}{$\begin{array}{l}\text { Secondary matched, transfused }>72 \text { hours } \\
\text { after admission }\end{array}$} & \multicolumn{5}{|c|}{ Secondary matched, transfused within 72 hours of admission, titer $\geq 1350$} \\
\hline & Total & Control & Case & PE & & Total & Control & Case & $\mathrm{PE}$ & & Total & Control & Case & PE & \\
\hline & $(N=224)$ & $(n=112)$ & $(n=112)$ & $(95 \% \mathrm{CI})^{*}$ & $P$ value & $(N=92)$ & $(n=61)$ & $(n=31)$ & $(95 \% \mathrm{CI})^{*}$ & $P$ value & $(N=243)$ & $(n=158)$ & $(n=85)$ & $(95 \% \mathrm{CI})^{*}$ & $P$ value \\
\hline \multicolumn{16}{|l|}{ Disposition, 28 days } \\
\hline Still admitted & $6(2.7)$ & $4(3.6)$ & $2(1.8)$ & $\begin{array}{l}2.18 \\
(0.38 \text { to } 12.57)\end{array}$ & 0.38 & $1(1.1)$ & $1(1.6)$ & $0(0.0)$ & & & $6(2.5)$ & $4(2.5)$ & $2(2.4)$ & $\begin{array}{r}1.17(0.20 \\
\text { to } 6.73)\end{array}$ & 0.86 \\
\hline Discharge & $205(91.5)$ & $98(87.5)$ & $107(95.5)$ & BO & & $78(84.8)$ & $52(85.2)$ & $26(83.9)$ & BO & & $222(91.4)$ & $140(88.6)$ & $82(96.5)$ & BO & \\
\hline Death & $13(5.8)$ & $10(8.9)$ & $3(2.7)$ & $\begin{array}{l}3.64 \\
\quad(1.05 \text { to } 12.62)\end{array}$ & 0.04 & $13(14.1)$ & $8(13.1)$ & $5(16.1)$ & $\begin{array}{l}0.80 \\
(0.20 \text { to } 3.27)\end{array}$ & 0.76 & $15(6.2)$ & $14(8.9)$ & $1(1.2)$ & $\begin{array}{l}8.20(1.19 \\
\quad \text { to } 56.36)\end{array}$ & 0.03 \\
\hline $\begin{array}{l}\text { Overall mortality with no } \\
\text { time constraints }\end{array}$ & & & & $\begin{array}{l}3.33 \\
\text { (1.01 to } 10.98)\end{array}$ & 0.048 & & & & $\begin{array}{l}0.81 \\
\quad(0.25 \text { to } 2.69)\end{array}$ & 0.74 & & & & $\begin{array}{l}7.53(1.12 \\
\text { to } 50.46)\end{array}$ & 0.04 \\
\hline Alive & $211(94.2)$ & $102(91.1)$ & $109(97.3)$ & & & $79(85.9)$ & $53(86.9)$ & $26(83.9)$ & & & $228(93.8)$ & $144(91.1)$ & $84(98.8)$ & & \\
\hline Dead & $13(5.8)$ & $10(8.9)$ & $3(2.7)$ & & & $13(14.1)$ & $8(13.1)$ & $5(16.1)$ & & & $15(6.2)$ & $14(8.9)$ & $1(1.2)$ & & \\
\hline $\begin{array}{l}\text { Overall mortality within } \\
28 \text { days post-day } 0\end{array}$ & & & & $\begin{array}{l}3.50 \\
\quad(0.87 \text { to } 14.08)\end{array}$ & 0.08 & & & & $\begin{array}{l}0.89 \\
\quad(0.24 \text { to } 3.30)\end{array}$ & 0.86 & & & & $\begin{array}{l}5.92(0.90 \\
\quad \text { to } 38.84)\end{array}$ & 0.06 \\
\hline Alive & $215(96.0)$ & $105(93.8)$ & $110(98.2)$ & & & $81(88.0)$ & $54(88.5)$ & $27(87.1)$ & & & $231(95.1)$ & $147(93.0)$ & $84(98.8)$ & & \\
\hline Dead & $9(4.0)$ & $7(6.3)$ & $2(1.8)$ & & & $11(12.0)$ & $7(11.5)$ & $4(12.9)$ & & & $12(4.9)$ & $11(7.0)$ & $1(1.2)$ & & \\
\hline $\begin{array}{l}\text { Length of stay post-day } \\
0 \text {, days }\end{array}$ & $\begin{array}{l}5.8 \\
\quad(3.0 \text { to } \\
11.8)\end{array}$ & $\begin{array}{l}5.6 \\
\quad(2.7 \text { to } \\
11.3)\end{array}$ & $\begin{array}{l}5.8 \\
\quad(3.7 \text { to } \\
13.1)\end{array}$ & $\begin{array}{l}0.19 \\
(-2.78 \text { to } 3.16)\end{array}$ & 0.9 & $\begin{array}{l}10.1 \\
\quad(5.6 \text { to } \\
15.6)\end{array}$ & $\begin{array}{l}7.5 \\
(4.6 \text { to } \\
11.6)\end{array}$ & $\begin{array}{l}11.7 \\
(7.8 \text { to } \\
20.7)\end{array}$ & $\begin{array}{l}-2.73 \\
(-6.83 \text { to } 1.37)\end{array}$ & 0.19 & $\begin{array}{l}5.4(2.9 \\
\text { to } 11.1)\end{array}$ & $\begin{array}{l}5.7(2.7 \\
\text { to } 11.1)\end{array}$ & $\begin{array}{l}5.1(3.0 \\
\text { to } 11.1)\end{array}$ & $\begin{array}{c}1.83(-0.87 \\
\text { to } 4.53)\end{array}$ & 0.19 \\
\hline Required ICU post-day 0 & & & & $\begin{array}{l}1.25 \\
\quad(0.99 \text { to } 1.57)\end{array}$ & 0.06 & & & & $\begin{array}{l}1.07 \\
(0.85 \text { to } 1.34)\end{array}$ & 0.57 & & & & $\begin{array}{r}1.39(1.01 \\
\text { to } 1.90)\end{array}$ & 0.04 \\
\hline No & $125(55.8)$ & $57(50.9)$ & $68(60.7)$ & & & $30(32.6)$ & $19(31.1)$ & $11(35.5)$ & & & $150(61.7)$ & $91(57.6)$ & $59(69.4)$ & & \\
\hline Yes & $99(44.2)$ & $55(49.1)$ & $44(39.3)$ & & & $62(67.4)$ & $42(68.9)$ & $20(64.5)$ & & & $93(38.3)$ & $67(42.4)$ & $26(30.6)$ & & \\
\hline $\begin{array}{l}\text { ICU length of stay post- } \\
\text { day } 0 \text {, days }\end{array}$ & $11.1 \pm 11.5$ & $10.2 \pm 12.3$ & $12.2 \pm 10.4$ & $\begin{array}{l}-2.04 \\
\quad(-6.68 \text { to } 2.60)\end{array}$ & 0.39 & $11.0 \pm 9.9$ & $10.1 \pm 10.2$ & $12.9 \pm 9.2$ & $\begin{array}{l}-2.79 \\
\quad(-7.85 \text { to } 2.26)\end{array}$ & 0.28 & $10.4 \pm 9.9$ & $9.7 \pm 9.6$ & $12.1 \pm 10.5$ & $\begin{array}{l}-2.33(-6.95 \\
\text { to } 2.30)\end{array}$ & 0.32 \\
\hline $\begin{array}{l}\text { Mechanical ventilation } \\
\text { requirement, post- } \\
\text { day } 0\end{array}$ & & & & $\begin{array}{l}1.13 \\
\quad(0.76 \text { to } 1.66)\end{array}$ & 0.55 & & & & $\begin{array}{l}0.86 \\
\quad(0.59 \text { to } 1.24)\end{array}$ & 0.41 & & & & $\begin{array}{r}1.57(0.99 \\
\text { to } 2.49)\end{array}$ & 0.054 \\
\hline No & $173(77.2)$ & $85(75.9)$ & $88(78.6)$ & & & $49(53.3)$ & $34(55.7)$ & $15(48.4)$ & & & $192(79.0)$ & $120(75.9)$ & $72(84.7)$ & & \\
\hline Yes & $51(22.8)$ & $27(24.1)$ & $24(21.4)$ & & & $43(46.7)$ & $27(44.3)$ & $16(51.6)$ & & & $51(21.0)$ & $38(24.1)$ & $13(15.3)$ & & \\
\hline $\begin{array}{l}\text { Mechanical } \\
\text { ventilationpost-day } \\
0 \text { if required, days }\end{array}$ & $19.5 \pm 18.3$ & $20.7 \pm 22.9$ & $18.2 \pm 11.6$ & $\begin{array}{l}2.47 \\
(-7.55 \text { to } 12.50)\end{array}$ & 0.63 & $17.8 \pm 16.5$ & $17.5 \pm 19.5$ & $18.2 \pm 10.3$ & $\begin{array}{l}-0.69 \\
\quad(-8.38 \text { to } 7.00)\end{array}$ & 0.86 & $21.0 \pm 19.7$ & $20.5 \pm 21.7$ & $22.5 \pm 12.8$ & $\begin{array}{l}-2.02(-11.49 \\
\text { to } 7.45)\end{array}$ & 0.68 \\
\hline $\begin{array}{l}\text { Supplemental oxygen } \\
\text { post-day } 0\end{array}$ & & & & $\begin{array}{l}0.97 \\
\quad(0.91 \text { to } 1.03)\end{array}$ & & & & & $\begin{array}{l}1.02 \\
\quad(0.94 \text { to } 1.09)\end{array}$ & 0.67 & & & & $\begin{array}{r}0.94(0.89 \\
\text { to } 0.99)\end{array}$ & 0.02 \\
\hline No & $29(12.9)$ & $16(14.3)$ & $13(11.6)$ & & & $29(31.5)$ & $19(31.1)$ & $10(32.3)$ & & & $32(13.2)$ & $24(15.2)$ & $8(9.4)$ & & \\
\hline Yes & $195(87.1)$ & $96(85.7)$ & $99(88.4)$ & & 0.32 & $63(68.5)$ & $42(68.9)$ & $21(67.7)$ & & & $211(86.8)$ & $134(84.8)$ & $77(90.6)$ & & \\
\hline $\begin{array}{l}\text { Supplemental oxygen } \\
\text { post-day } 0 \text { if required, } \\
\text { days }\end{array}$ & $4.4 \pm 4.7$ & $4.0 \pm 4.8$ & $4.8 \pm 4.5$ & $\begin{array}{l}-0.81 \\
\quad(-2.18 \text { to } 0.57)\end{array}$ & 0.25 & $4.7 \pm 3.8$ & $4.1 \pm 3.3$ & $5.9 \pm 4.4$ & $\begin{array}{l}-1.77 \\
\quad(-3.99 \text { to } 0.44)\end{array}$ & 0.12 & $4.5 \pm 5.8$ & $4.6 \pm 6.7$ & $4.4 \pm 4.1$ & $\begin{array}{l}0.15(-1.37 \\
\quad \text { to } 1.67)\end{array}$ & 0.85 \\
\hline
\end{tabular}
post-day 0 if required,

Ventilation status at day 


\begin{tabular}{|c|c|c|c|c|c|c|c|c|c|c|c|c|c|c|c|}
\hline \multirow[b]{3}{*}{ Variable } & \multicolumn{5}{|c|}{ Secondary matched, transfused within 72 hours of admission } & \multicolumn{5}{|c|}{$\begin{array}{l}\text { Secondary matched, transfused }>72 \text { hours } \\
\text { after admission }\end{array}$} & \multicolumn{5}{|c|}{ Secondary matched, transfused within 72 hours of admission, titer $\geq 1350$} \\
\hline & \multirow{2}{*}{$\begin{array}{l}\text { Total } \\
(N=224)\end{array}$} & \multirow{2}{*}{$\frac{\text { Control }}{(n=112)}$} & \multirow{2}{*}{$\frac{\text { Case }}{(n=112)}$} & \multirow{2}{*}{$\frac{\mathrm{PE}}{(95 \% \mathrm{CI})^{*}}$} & \multirow[b]{2}{*}{$P$ value } & \multirow{2}{*}{$\begin{array}{l}\text { Total } \\
(N=92)\end{array}$} & \multirow{2}{*}{$\frac{\text { Control }}{(n=61)}$} & \multirow{2}{*}{$\frac{\text { Case }}{(n=31)}$} & $\mathrm{PE}$ & \multirow[b]{2}{*}{$P$ value } & \multirow{2}{*}{$\frac{\text { Total }}{(N=243)}$} & \multirow{2}{*}{$\frac{\text { Control }}{(n=158)}$} & \multirow{2}{*}{$\begin{array}{l}\text { Case } \\
(n=85)\end{array}$} & \multirow{2}{*}{$\frac{\mathrm{PE}}{(95 \% \mathrm{CI})^{\star}}$} & \multirow[b]{2}{*}{$P$ value } \\
\hline & & & & & & & & & $(95 \% \mathrm{CI})^{*}$ & & & & & & \\
\hline Room air & $20(8.9)$ & $10(8.9)$ & $10(8.9)$ & & & $9(9.8)$ & $6(9.8)$ & $3(9.7)$ & BO & & $30(12.3)$ & $20(12.7)$ & $10(11.8)$ & B0 & \\
\hline Low flow & $140(62.5)$ & $70(62.5)$ & $70(62.5)$ & & & $39(42.4)$ & $26(42.6)$ & $13(41.9)$ & $\begin{array}{l}1.00 \\
\quad(0.21 \text { to } 4.65)\end{array}$ & 1 & $173(71.2)$ & $116(73.4)$ & $57(67.1)$ & $\begin{array}{r}1.02(0.99 \\
\text { to } 1.04)\end{array}$ & 0.16 \\
\hline High flow/NIPPV & $40(17.9)$ & $20(17.9)$ & $20(17.9)$ & & & $18(19.6)$ & $12(19.7)$ & $6(19.4)$ & $\begin{array}{l}1.00 \\
\quad(0.18 \text { to } 5.46)\end{array}$ & 1 & $23(9.5)$ & $11(7.0)$ & $12(14.1)$ & $\begin{array}{r}0.46(0.39 \\
\text { to } 0.54)\end{array}$ & $<0.001$ \\
\hline Mechanical ventilation & $22(9.8)$ & $11(9.8)$ & $11(9.8)$ & & & $24(26.1)$ & $16(26.2)$ & $8(25.8)$ & $\begin{array}{l}1.00 \\
\quad(0.20 \text { to } 5.08)\end{array}$ & 1 & $16(6.6)$ & $10(6.3)$ & $6(7.1)$ & $\begin{array}{r}0.83(0.66 \\
\text { to } 1.05)\end{array}$ & 0.12 \\
\hline ECMO & $2(0.9)$ & $1(0.9)$ & $1(0.9)$ & & & $2(2.2)$ & $1(1.6)$ & $1(3.2)$ & $\begin{array}{l}0.50 \\
\quad(0.02 \text { to } 11.09)\end{array}$ & 0.66 & $1(0.4)$ & $1(0.6)$ & $0(0.0)$ & & \\
\hline Death & $0(0.0)$ & $0(0.0)$ & $0(0.0)$ & & & $0(0.0)$ & $0(0.0)$ & $0(0.0)$ & & & $0(0.0)$ & $0(0.0)$ & $0(0.0)$ & & \\
\hline \multicolumn{16}{|l|}{$\begin{array}{l}\text { Ventilation status at day } \\
\qquad 7\end{array}$} \\
\hline Room air & $133(59.4)$ & $70(62.5)$ & $63(56.3)$ & B0 & & $39(42.4)$ & $31(50.8)$ & $8(25.8)$ & BO & & $162(66.7)$ & $107(67.7)$ & $55(64.7)$ & B0 & \\
\hline Low flow & $27(12.1)$ & $10(8.9)$ & $17(15.2)$ & $\begin{array}{l}0.53 \\
\quad(0.22 \text { to } 1.28)\end{array}$ & 0.16 & $8(8.7)$ & $4(6.6)$ & $4(12.9)$ & $\begin{array}{l}0.26 \\
\quad(0.04 \text { to } 1.70)\end{array}$ & 0.16 & $23(9.5)$ & $12(7.6)$ & $11(12.9)$ & $\begin{array}{l}0.56(0.22 \\
\text { to } 1.46)\end{array}$ & 0.24 \\
\hline High flow/NIPPV & $14(6.3)$ & $5(4.5)$ & $9(8.0)$ & $\begin{array}{l}0.50 \\
(0.16 \text { to } 1.60)\end{array}$ & 0.24 & $6(6.5)$ & $2(3.3)$ & $4(12.9)$ & $\begin{array}{l}0.13 \\
\quad(0.03 \text { to } 0.65)\end{array}$ & 0.01 & $15(6.2)$ & $9(5.7)$ & $6(7.1)$ & $\begin{array}{l}0.77(0.29 \\
\quad \text { to } 2.03)\end{array}$ & 0.6 \\
\hline Mechanical ventilation & $41(18.3)$ & $23(20.5)$ & $18(16.1)$ & $\begin{array}{l}1.15 \\
\quad(0.65 \text { to } 2.03)\end{array}$ & 0.63 & $33(35.9)$ & $20(32.8)$ & $13(41.9)$ & $\begin{array}{l}0.40 \\
\quad(0.16 \text { to } 0.98)\end{array}$ & 0.04 & $39(16.0)$ & $27(17.1)$ & $12(14.1)$ & $\begin{array}{r}1.16(0.61 \\
\text { to } 2.19)\end{array}$ & 0.66 \\
\hline ECMO & $6(2.7)$ & $2(1.8)$ & $4(3.6)$ & $\begin{array}{l}0.45 \\
\quad(0.08 \text { to } 2.54)\end{array}$ & 0.37 & $4(4.3)$ & $2(3.3)$ & $2(6.5)$ & $\begin{array}{l}0.26 \\
\quad(0.03 \text { to } 2.33)\end{array}$ & 0.23 & $3(1.2)$ & $2(1.3)$ & $1(1.2)$ & $\begin{array}{l}1.03(0.26 \\
\text { to } 4.13)\end{array}$ & 0.97 \\
\hline Death & $3(1.3)$ & $2(1.8)$ & $1(0.9)$ & $\begin{array}{l}1.80 \\
(0.43 \text { to } 7.50)\end{array}$ & 0.42 & $2(2.2)$ & $2(3.3)$ & $0(0.0)$ & & & $1(0.4)$ & $1(0.6)$ & $0(0.0)$ & & \\
\hline \multicolumn{16}{|l|}{$\begin{array}{l}\text { Ventilation status at day } \\
\qquad 14\end{array}$} \\
\hline Room air & $180(80.4)$ & $90(80.4)$ & $90(80.4)$ & B0 & & $57(62.0)$ & $43(70.5)$ & $14(45.2)$ & BO & & $200(82.3)$ & $127(80.4)$ & $73(85.9)$ & B0 & \\
\hline Low flow & $4(1.8)$ & $1(0.9)$ & $3(2.7)$ & $\begin{array}{l}0.33 \\
(0.03 \text { to } 3.31)\end{array}$ & 0.35 & $3(3.3)$ & $1(1.6)$ & $2(6.5)$ & $\begin{array}{l}0.16 \\
\quad(0.01 \text { to } 2.00)\end{array}$ & 0.16 & $4(1.6)$ & $2(1.3)$ & $2(2.4)$ & $\begin{array}{l}0.57(0.08 \\
\text { to } 4.17)\end{array}$ & 0.58 \\
\hline High flow/NIPPV & $3(1.3)$ & $1(0.9)$ & $2(1.8)$ & $\begin{array}{l}0.50 \\
(0.04 \text { to } 5.74)\end{array}$ & 0.58 & $0(0.0)$ & $0(0.0)$ & $0(0.0)$ & $\begin{array}{l}0.33 \\
(0.15 \text { to } 0.73)\end{array}$ & 0.01 & $3(1.2)$ & $2(1.3)$ & $1(1.2)$ & $\begin{array}{l}1.15(0.10 \\
\text { to } 12.90)\end{array}$ & 0.91 \\
\hline Mechanical ventilation & $28(12.5)$ & $13(11.6)$ & $15(13.4)$ & $\begin{array}{l}0.87 \\
\quad(0.41 \text { to } 1.81)\end{array}$ & 0.7 & $22(23.9)$ & $11(18.0)$ & $11(35.5)$ & $\begin{array}{l}0.33 \\
\quad(0.02 \text { to } 5.77)\end{array}$ & 0.44 & $29(11.9)$ & $20(12.7)$ & $9(10.6)$ & $\begin{array}{l}1.28(0.55 \\
\text { to } 2.95)\end{array}$ & 0.57 \\
\hline ECMO & $3(1.3)$ & $2(1.8)$ & $1(0.9)$ & $\begin{array}{l}2.00 \\
(0.18 \text { to } 22.75)\end{array}$ & 0.58 & $2(2.2)$ & $1(1.6)$ & $1(3.2)$ & $\begin{array}{l}0.54 \\
(0.09 \text { to } 3.20)\end{array}$ & 0.5 & $1(0.4)$ & $1(0.6)$ & $0(0.0)$ & & \\
\hline Death & $6(2.7)$ & $5(4.5)$ & $1(0.9)$ & $\begin{array}{l}5.00 \\
(0.85 \text { to } 29.46)\end{array}$ & 0.08 & $8(8.7)$ & $5(8.2)$ & $3(9.7)$ & & & $6(2.5)$ & $6(3.8)$ & $0(0.0)$ & & \\
\hline \multicolumn{16}{|l|}{$\begin{array}{l}\text { Ventilation status at day } \\
\qquad 28\end{array}$} \\
\hline Room air & $200(89.3)$ & $97(86.6)$ & $103(92.0)$ & & & $74(80.4)$ & $49(80.3)$ & $25(80.6)$ & BO & & $212(87.2)$ & $134(84.8)$ & $78(91.8)$ & B0 & \\
\hline Low flow & $1(0.4)$ & $1(0.9)$ & $0(0.0)$ & & & $0(0.0)$ & $0(0.0)$ & $0(0.0)$ & & & $2(0.8)$ & $2(1.3)$ & $0(0.0)$ & & \\
\hline High flow/NIPPV & $0(0.0)$ & $0(0.0)$ & $0(0.0)$ & & & $0(0.0)$ & $0(0.0)$ & $0(0.0)$ & & & $0(0.0)$ & $0(0.0)$ & $0(0.0)$ & $\begin{array}{l}0.97(0.35 \\
\text { to } 2.66)\end{array}$ & 0.95 \\
\hline Mechanical ventilation & $11(4.9)$ & $5(4.5)$ & $6(5.4)$ & $\begin{array}{l}0.88 \\
\quad(0.29 \text { to } 2.75)\end{array}$ & 0.83 & $6(6.5)$ & $4(6.6)$ & $2(6.5)$ & $\begin{array}{l}1.02 \\
\quad(0.16 \text { to } 6.52)\end{array}$ & 0.98 & $16(6.6)$ & $10(6.3)$ & $6(7.1)$ & & \\
\hline
\end{tabular}




\begin{tabular}{|c|c|c|c|c|c|c|c|c|c|c|c|c|c|c|c|}
\hline \multirow[b]{3}{*}{ Variable } & \multicolumn{5}{|c|}{ Secondary matched, transfused within 72 hours of admission } & \multicolumn{5}{|c|}{$\begin{array}{l}\text { Secondary matched, transfused }>72 \text { hours } \\
\text { after admission }\end{array}$} & \multicolumn{5}{|c|}{ Secondary matched, transfused within 72 hours of admission, titer $\geq 1350$} \\
\hline & Total & Control & Case & PE & & Total & Control & Case & $\mathrm{PE}$ & & Total & Control & Case & $\mathrm{PE}$ & \\
\hline & $(N=224)$ & $(n=112)$ & $(n=112)$ & $(95 \% \mathrm{CI})^{*}$ & $P$ value & $(N=92)$ & $(n=61)$ & $(n=31)$ & $(95 \% \mathrm{CI})^{\star}$ & $P$ value & $(N=243)$ & $(n=158)$ & $(n=85)$ & $(95 \% \mathrm{CI})^{\star}$ & $P$ value \\
\hline ECMO & $3(1.3)$ & $2(1.8)$ & $1(0.9)$ & $\begin{array}{l}2.12 \\
(0.18 \text { to } 24.49)\end{array}$ & 0.55 & $1(1.1)$ & $1(1.6)$ & $0(0.0)$ & & & $1(0.4)$ & $1(0.6)$ & $0(0.0)$ & & \\
\hline Death & $9(4.0)$ & $7(6.3)$ & $2(1.8)$ & $\begin{array}{l}3.72 \\
\quad(0.89 \text { to } 15.51)\end{array}$ & 0.07 & $11(12.0)$ & $7(11.5)$ & $4(12.9)$ & $\begin{array}{l}0.89 \\
\quad(0.20 \text { to } 4.02)\end{array}$ & 0.88 & $12(4.9)$ & $11(7.0)$ & $1(1.2)$ & $\begin{array}{l}6.40(0.97 \\
\text { to } 42.37)\end{array}$ & 0.054 \\
\hline $\begin{array}{l}\text { Clinical improvement } \\
\text { relative to day } 0 \text { at } \\
\text { day } 7\end{array}$ & & & & $\begin{array}{l}1.07 \\
\quad(0.89 \text { to } 1.29)\end{array}$ & 0.45 & & & & $\begin{array}{l}1.86 \\
\text { (1.07 to } 3.25)\end{array}$ & 0.03 & & & & $\begin{array}{l}0.95(0.80 \\
\text { to } 1.12)\end{array}$ & 0.53 \\
\hline No & $85(37.9)$ & $40(35.7)$ & $45(40.2)$ & & & $50(54.3)$ & $28(45.9)$ & $22(71.0)$ & & & $83(34.2)$ & $56(35.4)$ & $27(31.8)$ & & \\
\hline Yes & $139(62.1)$ & $72(64.3)$ & $67(59.8)$ & & & $42(45.7)$ & $33(54.1)$ & $9(29.0)$ & & & $160(65.8)$ & $102(64.6)$ & $58(68.2)$ & & \\
\hline $\begin{array}{l}\text { Clinical improvement } \\
\text { relative to day } 0 \text { at } \\
\text { day } 14\end{array}$ & & & & $\begin{array}{l}0.96 \\
\quad(0.86 \text { to } 1.07)\end{array}$ & 0.44 & & & & $\begin{array}{l}1.56 \\
\quad(1.06 \text { to } 2.30)\end{array}$ & 0.03 & & & & $\begin{array}{l}0.88(0.78 \\
\text { to } 0.98)\end{array}$ & 0.02 \\
\hline No & $42(18.8)$ & $23(20.5)$ & $19(17.0)$ & & & $35(38.0)$ & $18(29.5)$ & $17(54.8)$ & & & $46(18.9)$ & $36(22.8)$ & $10(11.8)$ & & \\
\hline Yes & $182(81.3)$ & 89 (79.5) & $93(83.0)$ & & & $57(62.0)$ & $43(70.5)$ & $14(45.2)$ & & & $197(81.1)$ & $122(77.2)$ & $75(88.2)$ & & \\
\hline $\begin{array}{l}\text { Clinical improvement } \\
\text { relative to day } 0 \text { at } \\
\text { day } 28\end{array}$ & & & & $\begin{array}{l}0.92 \\
\quad(0.84 \text { to } 1.01)\end{array}$ & 0.08 & & & & $\begin{array}{l}0.98 \\
\quad(0.78 \text { to } 1.22)\end{array}$ & 0.83 & & & & $\begin{array}{r}0.88(0.81 \\
\text { to } 0.96)\end{array}$ & 0.01 \\
\hline No & $26(11.6)$ & $17(15.2$ & $9(8.0)$ & & & 1 & 7 & $6(19$ & & & 37( & $30(1$ & $7(8.2)$ & & \\
\hline Yes & $198(88.4)$ & $95(84.8)$ & $103(92.0)$ & & & $73(79.3)$ & $48(78.7)$ & $25(80.6)$ & & & $206(84.8)$ & $128(81.0)$ & $78(91.8)$ & & \\
\hline $\begin{array}{l}\mathrm{IL}-6 \delta \text { (day 7-day 0), } \\
\mathrm{pg} / \mathrm{mL}\end{array}$ & $\begin{array}{l}36.0 \\
(-56.0 \text { to } \\
600.0)\end{array}$ & $\begin{array}{l}-4.0 \\
\quad(-69.0 \text { to } \\
334.0)\end{array}$ & $\begin{array}{l}39.0 \\
(-50.0 \text { to } \\
885.0)\end{array}$ & $\begin{array}{l}8.13 \\
\quad(-927.39 \text { to } \\
943.66)\end{array}$ & 0.99 & $\begin{array}{l}108.0 \\
\quad(-6.0 \text { to } \\
931.0)\end{array}$ & $\begin{array}{l}108.0 \\
(-112.0 \text { to } \\
1397.0)\end{array}$ & $\begin{array}{c}135.5 \\
(0.5 \text { to } \\
752.0)\end{array}$ & $\begin{array}{l}334.51 \\
\quad(-834.70 \text { to } \\
1503.72)\end{array}$ & 0.58 & $\begin{array}{r}39.5(-34.0 \\
\text { to } 619.0)\end{array}$ & $\begin{array}{r}-4.0(-35.0 \\
\text { to } 218.0)\end{array}$ & $\begin{array}{r}95.0(-15.0 \\
\text { to } 886.0)\end{array}$ & $\begin{array}{l}-44.16 \\
\quad(-994.43 \\
\text { to } 906.10)\end{array}$ & 0.93 \\
\hline $\begin{array}{l}\text { C-reactive protein } \delta \text { (day } \\
\text { 7-day 0), } \mathrm{mg} / \mathrm{dL}\end{array}$ & $\begin{array}{l}-9.9 \\
\quad(-19.0 \\
\text { to }-2.9)\end{array}$ & $\begin{array}{l}-11.9 \\
(-22.3 \text { to } \\
-2.2)\end{array}$ & $\begin{array}{l}-8.2 \\
\quad(-16.9 \text { to } \\
-3.0)\end{array}$ & $\begin{array}{l}-1.66 \\
\quad(-6.44 \text { to } 3.12)\end{array}$ & 0.5 & $\begin{array}{l}-4.6 \\
(-15.3 \text { to } \\
2.9)\end{array}$ & $\begin{array}{l}-6.8 \\
\quad(-13.7 \\
\text { to }-2.2)\end{array}$ & $\begin{array}{r}-1.0 \\
\quad(-16.8 \\
\text { to } 6.1)\end{array}$ & $\begin{array}{l}-6.71 \\
\quad(-16.19 \text { to } 2.76)\end{array}$ & 0.17 & $\begin{array}{l}-7.7(-17.6 \\
\quad \text { to }-1.8)\end{array}$ & $\begin{array}{l}-7.3(-16.3 \\
\text { to }-1.5)\end{array}$ & $\begin{array}{l}-8.7(-19.7 \\
\text { to }-3.1)\end{array}$ & $\begin{array}{l}2.92(-2.47 \\
\text { to } 8.31)\end{array}$ & 0.29 \\
\hline $\begin{array}{l}\text { Ferritin } \delta \text { (day 7-day 0), } \\
\mathrm{ng} / \mathrm{mL}\end{array}$ & $\begin{array}{l}-14.0 \\
\quad(-419.0 \\
\text { to } 325.0)\end{array}$ & $\begin{array}{l}-48.0 \\
\quad(-658.0 \text { to } \\
268.0)\end{array}$ & $\begin{array}{l}16.5 \\
(-233.0 \text { to } \\
426.0)\end{array}$ & $\begin{array}{l}207.42 \\
\quad(-1009.76 \text { to } \\
1424.60)\end{array}$ & 0.74 & $\begin{array}{l}72.5 \\
(-229.0 \text { to } \\
492.0)\end{array}$ & $\begin{array}{l}-48.0 \\
\quad(-438.0 \\
\text { to } 201.0)\end{array}$ & $\begin{array}{l}400.0 \\
\quad(37.0 \text { to } \\
871.0)\end{array}$ & $\begin{array}{l}-1240.42 \\
\quad(-2473.33 \text { to } \\
-7.51)\end{array}$ & 0.049 & $\begin{array}{l}-34.0(-323.0 \\
\text { to } 149.0)\end{array}$ & $\begin{array}{l}-47.0(-438.0 \\
\text { to } 130.0)\end{array}$ & $\begin{array}{r}0.5(-294.5 \\
\text { to } 345.5)\end{array}$ & $\begin{array}{l}-36.98 \\
\quad(-692.67 \\
\quad \text { to } 618.70)\end{array}$ & 0.91 \\
\hline $\begin{array}{l}\text { Fibrinogen } \delta \text { (day } \\
\quad 7 \text {-day } 0 \text { ), } \mathrm{mg} / \mathrm{dL}\end{array}$ & $\begin{array}{l}-208.0 \\
(-381.5 \\
\text { to }-51.0)\end{array}$ & $\begin{array}{l}-219.0 \\
\quad(-376.0 \text { to } \\
-48.0)\end{array}$ & $\begin{array}{c}-197.0 \\
(-387.0 \text { to } \\
-63.0)\end{array}$ & $\begin{array}{l}-22.83 \\
\quad(-142.72 \text { to } \\
97.06)\end{array}$ & 0.71 & $\begin{array}{l}-94.0 \\
\quad(-401.0 \\
\text { to } 1.0)\end{array}$ & $\begin{array}{l}-401.0 \\
\quad(-426.0 \\
\text { to }-94.0)\end{array}$ & $\begin{array}{l}9.5 \\
\quad(-172.0 \\
\text { to } 209.0)\end{array}$ & $\begin{array}{l}-334.63 \\
\quad(-575.73 \text { to } \\
-93.52)\end{array}$ & 0.01 & $\begin{array}{l}-194.0(-376.0 \\
\text { to }-48.0)\end{array}$ & $\begin{array}{l}-192.0(-324.0 \\
\text { to }-37.0)\end{array}$ & $\begin{array}{l}-241.0 \\
\quad(-408.0 \\
\text { to }-67.0)\end{array}$ & $\begin{array}{l}28.87 \\
\quad(-126.77 \\
\text { to } 184.51)\end{array}$ & 0.72 \\
\hline $\begin{array}{l}\text { D-dimer } \delta \text { (day 7-day 0), } \\
\mu \mathrm{g} / \mathrm{mL} \text { FEU }\end{array}$ & $\begin{array}{l}0.2 \\
(-0.3 \text { to } \\
2.5)\end{array}$ & $\begin{array}{l}0.2 \\
(-0.4 \text { to } \\
2.4)\end{array}$ & $\begin{array}{l}0.2 \\
(-0.2 \text { to } \\
2.6)\end{array}$ & $\begin{array}{l}-1.36 \\
(-3.64 \text { to } 0.92)\end{array}$ & 0.24 & $\begin{array}{l}1.1 \\
(0.0 \text { to } \\
2.8)\end{array}$ & $\begin{array}{l}0.7 \\
\quad(-0.1 \\
\text { to } 2.8)\end{array}$ & $\begin{array}{l}1.3 \\
(0.3 \text { to } \\
4.4)\end{array}$ & $\begin{array}{l}-2.24 \\
\quad(-4.49 \text { to } 0.01)\end{array}$ & 0.051 & $\begin{array}{r}0.2(-0.3 \\
\text { to } 1.7)\end{array}$ & $\begin{array}{r}0.1(-0.5 \\
\text { to } 1.5)\end{array}$ & $\begin{array}{r}0.5(-0.2 \\
\text { to } 1.9)\end{array}$ & $\begin{array}{l}-2.11(-4.65 \\
\text { to } 0.43)\end{array}$ & 0.1 \\
\hline
\end{tabular}

Values are in median (IQR) for continuous variables and $n(\%)$ for categorical variables.

*PE obtained from the generalized linear models (for binary and continuous dependent variables) or multinomial logistic regression (for categorical dependent variables), which is risk ratio of outcome in nontransfusion versus transfusion (if categorical outcomes) or coefficient of outcome in non-transfusion versus transfusion (if continuous outcomes).

BO, base outcome; ECMO, extracorporeal membrane oxygenation; FEU, fibrinogen equivalent units; ICU, intensive care unit; IQR, interquartile range; NIPPV, noninvasive positive-pressure ventilation; PE, point estimate. 
non-transfused patients), ribavirin (higher in non-transfused patients), and tocilizumab (higher in transfused patients). Thus, this study has not yet completely addressed the potential for variations in background standard of care and period effect as sources of confounding in our data set, although a significant difference in the distribution of date of death over the study period between overall secondarymatched cases and controls is not observed. As our population of cases and controls who meet a 28-day outcome increases, additional matching approaches may be included, and these may impact future findings. Third, the strict matching criteria used in this study resulted in small sample sizes in the subanalyses, prohibiting multivariate analysis. Fourth, there was heterogeneity in the administration of two transfusions versus one based on inventory limitations early in the study and on patient enrollment in other trials that excluded redosing of convalescent plasma. Fifth, this study did not exclude non-transfused control patients if they were enrolled in other clinical trials. This is likely to be a small minority of control patients, as all clinical trials for COVID19 therapies in our system, other than convalescent plasma, were only offered at our flagship hospital in the Texas Medical Center. Access to these enrollment lists in the future will allow for such exclusion. Sixth, this interim analysis was based on data available in the electronic health record. Finally, the results reflect the experience of a system of eight hospitals in the Houston metropolitan region and may not be applicable to all centers. However, it is notable that our hospital system serves a metropolitan region with a highly diverse population of 7 million people.

In conclusion, this interim propensity score-matched analysis suggests that transfusion of high anti-RBD IgG titer COVID-19 convalescent plasma early in hospitalization reduces mortality in COVID-19 patients.

\section{Acknowledgments}

We thank all of our volunteer plasma donors for time, generous gift, and solidarity; Katharine G. Dlouhy, Curt Hampton, and their team of coordinators and recruiters for outstanding efforts; Monisha Dey and Cheryl Chavez-East, for managing the donor center; Kate Cody, Sayali Kelkar, Belimat Askary, and the clinical analytics team for assistance with data acquisition and management; Drs. Jessica Thomas and Zejuan Li, Erika Walker, the molecular technologists, and the labor pool volunteers in the Molecular Diagnostics Laboratory for dedication to patient care; the donor center and blood bank phlebotomists and technologists for dedication to donor and blood safety; Kathryn Stockbauer, Sasha Pejerrey, Adrienne Winston, and Heather McConnell for editorial assistance; Claude Moussa, Heather Patton, and other members of our laboratory information technology team for implementing the electronic workflows; Pamela McShane, Dilzi Mody, and members of the biorepository team for management of patient samples;
Christina Talley, Susan Miller, and Mary Clancy for advice; Manuel Hinojosa and Mark Vassallo for procuring resources; Drs. Marc Boom and Dirk Sostman for support; many Houston citizens and businesses for philanthropic support, including but not limited to anonymous, Ann and John Bookout III, Carolyn and John Bookout, Ting Tsung and Wei Fong Chao Foundation, Ann and Leslie Doggett, Freeport LNG, the Hearst Foundations, Jerold B. Katz Foundation, C. James and Carole Walter Looke, Diane and David Modesett, the Sherman Foundation, Paula and Joseph C. "Rusty" Walter III, and Aramco Americas; Dr. Jason S. McLellan (University of Texas at Austin) for providing the monoclonal antibody CR3022 and the spike protein expression vectors; the Center for Systems and Synthetic Biology at the University of Texas at Austin for technical assistance; and Terumo BCT for supplying blood collection devices and supplies.

J.M.M. is the guarantor of this work and, as such, had full access to all of the data in the study and takes responsibility for the integrity of the data and the accuracy of the data analysis.

\section{Supplemental Data}

Supplemental material for this article can be found at http://doi.org/10.1016/j.ajpath.2020.08.001.

\section{References}

1. Fragkou PC, Belhadi D, Peiffer-Smadja N, Moschopoulos CD, Lescure FX, Janocha H, Karofylakis E, Yazdanpanah Y, Mentre F, Skevaki C, Laouenan C, Tsiodras S; ESCMID Study Group for Respiratory Viruses: Review of trials currently testing treatment and prevention of COVID-19. Clin Microbiol Infect 2020, 26:988-998

2. Mehta HB, Ehrhardt S, Moore TJ, Segal JB, Alexander GC: Characteristics of registered clinical trials assessing treatments for COVID-19: a cross-sectional analysis. BMJ Open 2020, 10:e039978

3. Nasrallah AA, Farran SH, Nasrallah ZA, Chahrour MA, Salhab HA, Fares MY, Khachfe HH, Akl EA: A large number of COVID-19 interventional clinical trials were registered soon after the pandemic onset: a descriptive analysis. J Clin Epidemiol 2020, 125: $170-178$

4. Sheahan TP, Sims AC, Graham RL, Menachery VD, Gralinski LE, Case JB, Leist SR, Pyrc K, Feng JY, Trantcheva I, Bannister R, Park Y, Babusis D, Clarke MO, Mackman RL, Spahn JE, Palmiotti CA, Siegel D, Ray AS, Cihlar T, Jordan R, Denison MR, Baric RS: Broad-spectrum antiviral GS-5734 inhibits both epidemic and zoonotic coronaviruses. Sci Transl Med 2017, 9:eaal3653

5. Beigel JH, Tomashek KM, Dodd LE, Mehta AK, Zingman BS, Kalil AC, et al: Remdesivir for the treatment of Covid-19: preliminary report. N Engl J Med 2020, 383. NEJMoa2007764

6. Horby P, Lim WS, Emberson J, Mafham M, Bell J, Linsell L, Staplin N, Brightling C, Ustianowski A, Elmahi E, Prudon B, Green C, Felton T, Chadwick D, Rege K, Fegan C, Chappell LC, Faust SN, Jaki T, Jeffery K, Montgomery A, Rowan K, Juszczak E, Baillie JK, Haynes R, Landray MJ: Dexamethasone in hospitalized patients with COVID-19: preliminary report. N Engl J Med 2020, [Epub ahead of print] doi:10.1056/NEJMoa2021436

7. ISRCTN Registry: A Phase III Study to Investigate a Vaccine Against COVID-19; 2020. doi:10.1186/ISRCTN89951424 
8. Amanat F, Krammer F: SARS-CoV-2 vaccines: status report. Immunity 2020, 52:583-589

9. Chen WH, Strych U, Hotez PJ, Bottazzi ME: The SARS-CoV-2 vaccine pipeline: an overview. Curr Trop Med Rep 2020, [Epub ahead of print] doi:10.1007/s40475-020-00201-6

10. Cheng Y, Wong R, Soo YO, Wong WS, Lee CK, Ng MH, Chan P, Wong $\mathrm{KC}$, Leung $\mathrm{CB}$, Cheng $\mathrm{G}$ : Use of convalescent plasma therapy in SARS patients in Hong Kong. Eur J Clin Microbiol Infect Dis 2005, 24:44-46

11. Soo YO, Cheng Y, Wong R, Hui DS, Lee CK, Tsang KK, Ng MH, Chan P, Cheng G, Sung JJ: Retrospective comparison of convalescent plasma with continuing high-dose methylprednisolone treatment in SARS patients. Clin Microbiol Infect 2004, 10:676-678

12. Arabi YM, Hajeer AH, Luke T, Raviprakash K, Balkhy H, Johani S, Al-Dawood A, Al-Qahtani S, Al-Omari A, Al-Hameed F, Hayden FG, Fowler R, Bouchama A, Shindo N, Al-Khairy K, Carson G, Taha Y, Sadat M, Alahmadi M: Feasibility of using convalescent plasma immunotherapy for MERS-CoV infection, Saudi Arabia. Emerg Infect Dis 2016, 22:1554-1561

13. Ko JH, Seok H, Cho SY, Ha YE, Baek JY, Kim SH, Kim YJ, Park JK, Chung CR, Kang ES, Cho D, Müller MA, Drosten C, Kang CI, Chung DR, Song JH, Peck KR: Challenges of convalescent plasma infusion therapy in Middle East respiratory coronavirus infection: a single centre experience. Antivir Ther 2018, 23: $617-622$

14. Hung IF, To KK, Lee CK, Lee KL, Chan K, Yan WW, Liu R, Watt CL, Chan WM, Lai KY, Koo CK, Buckley T, Chow FL, Wong KK, Chan HS, Ching CK, Tang BS, Lau CC, Li IW, Liu SH, Chan KH, Lin CK, Yuen KY: Convalescent plasma treatment reduced mortality in patients with severe pandemic influenza A (H1N1) 2009 virus infection. Clin Infect Dis 2011, 52:447-456

15. van Griensven J, Edwards $T$, de Lamballerie X, Semple MG, Gallian P, Baize S, Horby PW, Raoul H, Magassouba N, Antierens A, Lomas C, Faye O, Sall AA, Fransen K, Buyze J, Ravinetto R, Tiberghien P, Claeys Y, De Crop M, Lynen L, Bah EI, Smith PG, Delamou A, De Weggheleire A, Haba N; Ebola-Tx Consortium: Evaluation of convalescent plasma for Ebola virus disease in Guinea. N Engl J Med 2016, 374:33-42

16. Casadevall A, Pirofski LA: The convalescent sera option for containing COVID-19. J Clin Invest 2020, 130:1545-1548

17. Joyner MJ, Wright RS, Fairweather D, Senefeld JW, Bruno KA, Klassen SA, et al: Early safety indicators of COVID-19 convalescent plasma in 5,000 patients. J Clin Invest 2020, 130:4791-4797

18. Duan K, Liu B, Li C, Zhang H, Yu T, Qu J, et al: Effectiveness of convalescent plasma therapy in severe COVID-19 patients. Proc Natl Acad Sci U S A 2020, 117:9490-9496

19. Salazar E, Perez KK, Ashraf M, Chen J, Castillo B, Christensen PA, Eubank T, Bernard DW, Eagar TN, Long SW, Subedi S, Olsen RJ, Leveque C, Schwartz MR, Dey M, Chavez-East C, Rogers J, Shehabeldin A, Joseph D, Williams G, Thomas K, Masud F, Talley C, Dlouhy KG, Lopez BV, Hampton C, Lavinder J, Gollihar JD, Maranhao AC, Ippolito GC, Saavedra MO, Cantu CC, Yerramilli P, Pruitt L, Musser JM: Treatment of coronavirus disease 2019 (COVID-19) patients with convalescent plasma. Am J Pathol 2020, 190:1680-1690

20. Shen C, Wang Z, Zhao F, Yang Y, Li J, Yuan J, Wang F, Li D, Yang M, Xing L, Wei J, Xiao H, Yang Y, Qu J, Qing L, Chen L, Xu Z, Peng L, Li Y, Zheng H, Chen F, Huang K, Jiang Y, Liu D, Zhang Z, Liu Y, Liu L: Treatment of 5 critically ill patients with COVID-19 with convalescent plasma. JAMA 2020, 323: $1582-1589$

21. Ye M, Fu D, Ren Y, Wang F, Wang D, Zhang F, Xia X, Lv T: Treatment with convalescent plasma for COVID-19 patients in Wuhan, China. J Med Virol 2020, [Epub ahead of print] doi: 10.1002/ jmv. 25882

22. Zeng QL, Yu ZJ, Gou JJ, Li GM, Ma SH, Zhang GF, Xu JH, Lin WB, Cui GL, Zhang MM, Li C, Wang ZS, Zhang ZH, Liu ZS
Effect of convalescent plasma therapy on viral shedding and survival in COVID-19 patients. J Infect Dis 2020, 222:38-43

23. Zhang B, Liu S, Tan T, Huang W, Dong Y, Chen L, Chen Q, Zhang L, Zhong Q, Zhang X, Zou Y, Zhang S: Treatment with convalescent plasma for critically ill patients with SARS-CoV-2 infection. Chest 2020, 158:e9-e13

24. Corman VM, Landt O, Kaiser M, Molenkamp R, Meijer A, Chu DKW, Bleicker T, Brünink S, Schneider J, Schmidt ML, Mulders D, Haagmans BL, van der Veer B, van den Brink S, Wijsman L, Goderski G, Romette JL, Ellis J, Zambon M, Peiris M, Goossens H, Reusken C, Koopmans MPG, Drosten C: Detection of 2019 novel coronavirus (2019-nCoV) by real-time RT-PCR. Euro Surveill 2020, 25:2000045

25. Salazar E, Kuchipudi SV, Christensen PA, Eagar TN, Yi X, Zhao P, Jin Z, Long SW, Olsen RJ, Chen J, Castillo B, Leveque C, Towers DM, Lavinder J, Gollihar JD, Cardona J, Ippolito GC, Nissly RH, Bird IM, Greenawalt D, Rossi RM, Gontu A, Srinivasan S, Poojary IB, Cattadori IM, Hudson PJ, Joselyn N, Prugar L, Huie K, Herbert A, Bernard DW, Dye J, Kapur V, Musser JM: Relationship between anti-spike protein antibody titers and SARS-CoV-2 in vitro virus neutralization in convalescent plasma. [Epub] bioRxiv 2020. 2020.06.08.138990

26. Prevention USCfDCa: The National Healthcare Safety Network (NHSN) Manual: Biovigilance Component v2.5. Atlanta, GA, Division of Healthcare Quality Promotion, National Center for Emerging and Zoonotic Infectious Diseases., 2020

27. Tian X, Li C, Huang A, Xia S, Lu S, Shi Z, Lu L, Jiang S, Yang Z, Wu Y, Ying T: Potent binding of 2019 novel coronavirus spike protein by a SARS coronavirus-specific human monoclonal antibody. Emerg Microbes Infect 2020, 9:382-385

28. Liu STH, Lin H-M, Baine I, Wajnberg A, Gumprecht JP, Rahman F, Rodriguez D, Tandon P, Bassily-Marcus A, Bander J, Sanky C, Dupper A, Zheng A, Altman DR, Chen BK, Krammer F, Mendu DR, Firpo-Betancourt A, Levin MA, Bagiella E, Casadevall A, Cordon-Cardo C, Jhang JS, Arinsburg SA, Reich DL, Aberg JA, Bouvier NM: Convalescent plasma treatment of severe COVID-19: a propensity score-matched control study. Nat Med 2020, [Epub ahead of print] doi:10.1038/s41591-020-1088-9

29. Hastie T, Tibshirani R, Wainwright M: Statistical Learning with Sparsity: The Lasso and Generalizations. Boca Raton, FL, CRC Press, 2015

30. Lasso SS: Stata Reference Manual, ed 16. College Station, TX: Stata Press, 2020

31. Eckhardt CM, Cummings MJ, Rajagopalan KN, Borden S, Bitan ZC, Wolf A, Kantor A, Briese T, Meyer BJ, Jacobson SD, Scotto D, Mishra N, Philip NM, Stotler BA, Schwartz J, Shaz B, Spitalnik SL, Eisenberger A, Hod EA, Justman J, Cheung K, Lipkin WI, O'Donnell MR: Evaluating the efficacy and safety of human antiSARS-CoV-2 convalescent plasma in severely ill adults with COVID-19: a structured summary of a study protocol for a randomized controlled trial. Trials 2020, 21:499

32. Gharbharan A, Jordans CCE, GeurtsvanKessel C, den Hollander JG, Karim F, Mollema FPN, Stalenhoef JE, Dofferhoff A, Ludwig I, Koster A, Hassing R-J, Bos JC, van Pottelberge GR, Vlasveld IN, Ammerlaan HSM, Segarceanu E, Miedema J, van der Eerden M, Papageorgiou G, te Broekhorst P, Swaneveld FH, Katsikis PD, Mueller Y, Okba NMA, Koopmans MPG, Haagmans BL, Rokx C, Rijnders B: Convalescent plasma for COVID-19: a randomized clinical trial. medRxiv 2020. doi:10.1101/2020.07.01.20139857

33. Hegerova L, Gooley T, Sweerus KA, Maree CL, Bailey N, Bailey M, Dunleavy V, Patel K, Alcorn K, Haley NR, Johnsen JM, Konkle BA, Lahti AC, Alexander ML, Goldman JD, Lipke A, Lim SJ, Sullivan MD, Pauk JS, Pagel JM: Use of convalescent plasma in hospitalized patients with Covid-19: case series. Blood 2020, 136 : $759-762$

34. Li L, Zhang W, Hu Y, Tong X, Zheng S, Yang J, Kong Y, Ren L, Wei Q, Mei H, Hu C, Tao C, Yang R, Wang J, Yu Y, Guo Y, Wu X, 
Xu Z, Zeng L, Xiong N, Chen L, Wang J, Man N, Liu Y, Xu H, Deng E, Zhang X, Li C, Wang C, Su S, Zhang L, Wang J, Wu Y, Liu Z: Effect of convalescent plasma therapy on time to clinical improvement in patients with severe and life-threatening COVID-19: a randomized clinical trial. JAMA 2020, 324:1-11

35. Lan J, Ge J, Yu J, Shan S, Zhou H, Fan S, Zhang Q, Shi X, Wang Q, Zhang L, Wang X: Structure of the SARS-CoV-2 spike receptor-binding domain bound to the ACE2 receptor. Nature 2020, 581:215-220

36. Walls AC, Park YJ, Tortorici MA, Wall A, McGuire AT, Veesler D: Structure, function, and antigenicity of the SARS-CoV-2 spike glycoprotein. Cell 2020, 181:281-292.e6

37. Casadevall A, Dadachova E, Pirofski LA: Passive antibody therapy for infectious diseases. Nat Rev Microbiol 2004, 2:695-703

38. Joyner MJ, Bruno KA, Klassen SA, Kunze KL, Johnson P, Lesser ER, et al: Safety update: COVID-19 convalescent plasma in 20,000 hospitalized patients. Mayo Clin Proc 2020, 95:1888-1897
39. Mair-Jenkins J, Saavedra-Campos M, Baillie JK, Cleary P, Khaw FM, Lim WS, Makki S, Rooney KD, Nguyen-Van-Tam JS, Beck CR; Convalescent Plasma Study Group: The effectiveness of convalescent plasma and hyperimmune immunoglobulin for the treatment of severe acute respiratory infections of viral etiology: a systematic review and exploratory meta-analysis. J Infect Dis 2015, 211:80-90

40. Hung IFN, To KKW, Lee CK, Lee KL, Yan WW, Chan K, Chan WM, Ngai CW, Law KI, Chow FL, Liu R, Lai KY, Lau CCY, Liu SH, Chan KH, Lin CK, Yuen KY: Hyperimmune IV immunoglobulin treatment: a multicenter double-blind randomized controlled trial for patients with severe 2009 influenza A(H1N1) infection. Chest 2013, 144:464-473

41. Finland M: The serum treatment of lobar pneumonia. N Engl J Med 1930, 202:1244-1247

42. Cecil RL: Remarks on THE SERUM TREATMENT OF PNEUMONIA. Br Med J 1932, 2:657-662 